Pace University

DigitalCommons@Pace

2012

\title{
Investor Protection Meets the Federal Arbitration Act
}

Jill I. Gross

Elisabeth Haub School of Law at Pace University

Follow this and additional works at: https://digitalcommons.pace.edu/lawfaculty

Part of the Consumer Protection Law Commons, Dispute Resolution and Arbitration Commons, and the Securities Law Commons

\section{Recommended Citation}

Jill I. Gross \& Barbara Black, Investor Protection Meets the Federal Arbitration Act, 1 Stan. J. Complex Litig. 1 (2012), http://digitalcommons.pace.edu/lawfaculty/919/.

This Article is brought to you for free and open access by the School of Law at DigitalCommons@Pace. It has been accepted for inclusion in Pace Law Faculty Publications by an authorized administrator of DigitalCommons@Pace. For more information, please contact dheller2@law.pace.edu. 


\title{
INVESTOR PROTECTION MEETS THE FEDERAL ARBITRATION ACT
}

\author{
Barbara Black* and Jill I. Gross**
}

\begin{abstract}
In the past three decades, most recently in AT\&T Mobility LLC $v$. Concepcion, the United States Supreme Court has advanced an aggressive proarbitration campaign, transforming the Federal Arbitration Act (FAA) into a powerful source of anti-consumer substantive arbitration law. In the aftermath of AT\&T Mobility, which upheld a prohibition on class actions in a consumer contract despite state law that refused to enforce such provisions on unconscionability grounds, efforts have been made to prohibit investors from bringing class actions or joining claims, including claims under the Securities Exchange Act of 1934 (the Exchange Act). In the most egregious example to date, the broker-dealer Charles Schwab \& Co. (Schwab) revised its customer account agreements to prohibit class actions and joinder of claims. When the Financial Industry Regulatory Authority (FINRA), the self-regulatory organization for broker-dealers, brought a disciplinary action against Schwab, claiming the revision violated FINRA rules, the broker-dealer sued FINRA, asserting that the FAA requires enforcement of its arbitration agreement. This confrontation provides a concrete opportunity to analyze how courts should resolve conflicts between the FAA and federal regulatory statutes designed to protect certain segments of the public, in this case, investors.

This Article addresses whether the FAA limits the ability of federal regulators acting pursuant to Congressional authority to impose conditions and limitations on the use of arbitration provisions in order to ensure fairness. In this Article, we summarize current Supreme Court FAA jurisprudence that establishes a strong national pro-arbitration policy. We then describe the Exchange Act's regulation of arbitration involving broker-dealers, specifically the authority delegated to the SEC and FINRA to regulate the content of arbitration clauses in broker-dealer/customer contracts and the Exchange Act's anti-waiver provision
\end{abstract}

\footnotetext{
* Charles Hartsock Professor of Law and Director, Corporate Law Center, University of Cincinnati College of Law. Professor Black was a member of the National Adjudicatory Council of FINRA from 2009-11. I am grateful for the research assistance of Michael Richardson, UC Law ' 12 and Bryan Wisecup, UC Law '14.

** Professor of Law, Director of Legal Skills and Director, Investor Rights Clinic, Pace Law School. Professor Gross was a member of FINRA's National Arbitration and Mediation Committee from 2006-09. I am grateful for the research assistance of Pace J.D. students Joan O'Connor Archer, JennyLynn Carey and Joelle Morabito.
} 
barring any condition that forces investors to waive compliance with any part of the Exchange Act, its rules and SRO rules. After detailing the current regulatory dispute between Schwab and FINRA over Schwab's inclusion of a class action waiver in its customer agreement, we argue that courts should resolve the conflict between the FAA and the Exchange Act by applying the Exchange Act over the FAA through the long-standing doctrine of implied repeal, additional wellaccepted canons of statutory construction, and current Exchange Act and FAA jurisprudence.

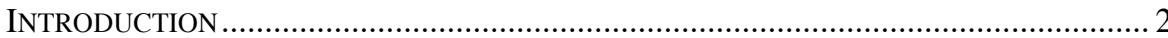

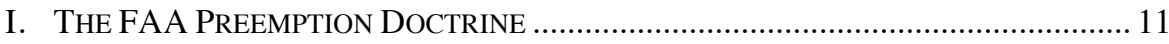

II. SEC AND FINRA REGULATION OF SECURITIES ARBITRATION PURSUANT

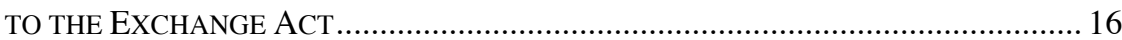

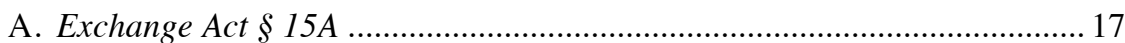

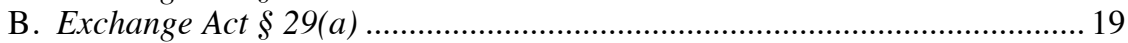

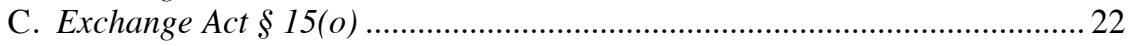

D. FINRA Rules at Issue in the Schwab Dispute ........................................ 24

1. Disclosures about the arbitration process; prohibiting inconsistent conditions (current FINRA Rule 2268) ........................................... 24

2. Class action claims (current FINRA Rules 12204, 2268(f)) ................ 27

3. Joinder of claims (current FINRA Rules 12312, 12313, 12314) .......... 29

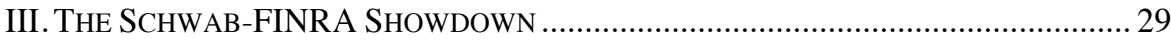

IV.RECONCILING THE CONFLICT BETWEEN THE FAA AND THE EXCHANGE

ACT.

A. The FAA is Impliedly Repealed by the Exchange Act .................................... 32

1. The traditional doctrine of implied repeal .............................................. 32

2. The Credit Suisse formulation of implied repeal ................................. 34

3. Precedent for implied repeal of the FAA .......................................... 35

4. The Exchange Act and FINRA Rules displace the FAA ......................... 37

5. Deference to SEC as an administrative agency ................................... 40

B. Exchange Act's Specific Rules Displace the FAA's General Mandate ........ 42

C. Arguments Not Limited to the Broker-Dealer Context................................ 44

1. The Exchange Act's anti-waiver provision ....................................... 44

2. The class action waiver is unenforceable because investors cannot vindicate their statutory rights ........................................................ 45

\section{INTRODUCTION}

The United States Supreme Court, in advancing an aggressive proarbitration campaign since the mid-1980s, transformed the Federal Arbitration Act (FAA) ${ }^{1}$ - enacted in 1925 and not amended materially since then - from a statute that forbids judicial discrimination against arbitration agreements to a powerful source of anti-consumer substantive arbitration law. ${ }^{2}$ Whether the

1. 9 U.S.C. $\S \S 1-16(2006)$.

2. Professor David Schwartz argues that the Court's decisions have converted the FAA into a "radical claim-suppressing statute." David S. Schwartz, Claim-Suppressing 
FAA is powerful enough to thwart the equally powerful and more recently reaffirmed federal policy of investor protection embodied in the Securities Exchange Act of 1934 (Exchange Act) ${ }^{3}$ remains an open issue the Court has not yet faced.

Primarily through the FAA preemption doctrine, ${ }^{4}$ the Court has struck down consumer-protective state laws that regulate arbitration agreements. In Doctor's Associates, Inc. v. Cassarotto, ${ }^{5}$ the Court held the FAA preempted a state statute that "singl[ed] out arbitration provisions for suspect status" 6 because it required contracts containing an arbitration clause to include prominent notice of the clause on the front page of the contract. Fifteen years later, in AT\&T Mobility LLC v. Concepcion, ${ }^{7}$ the Court upheld a provision in a consumer contract that disallowed class arbitration, finding the FAA preempted state precedent $^{8}$ that refused to enforce class arbitration waivers on unconscionability grounds. Strikingly, the Court found that the FAA preempted the state precedent even though it applied equally to waivers of class claims in court and in arbitration because, according to the Court, the "overarching purpose of the FAA ... is to ensure the enforcement of arbitration agreements according to their terms so as to facilitate streamlined proceedings." 9 Accordingly, corporations can not only require consumers of their products and services to arbitrate their disputes in a forum of the corporation's choice, they can also block consumers from aggregating their claims in court or in arbitration. Moreover, the corporation does not have to highlight the arbitration provision or in any way call it to consumers' attention.

Both Cassarotto and Concepcion involved conflicts between the FAA and state law. Subsequently, the Court, in CompuCredit Corp. v. Greenwood, ${ }^{10}$ reaffirmed the principle that parties may agree to arbitrate claims arising under a federal statute so long as the statute does not contain a "“contrary congressional command." 11 Although this was nothing more than a statement of the law in effect since Shearson/American Express Inc. v. McMahon, ${ }^{12}$ some

Arbitration: The New Rules, 87 IND. L.J. 239, 240 (2012).

3. 15 U.S.C. $\S \S 78 a-78 p p(2006$ \& Supp. V 2011).

4. See infra notes 71-77 and accompanying text.

5. 517 U.S. 681 (1996).

6. Id. at 687 .

7. 131 S.Ct. 1740 (2011).

8. Discover Bank v. Superior Court, 113 P.3d 1100, 1110 (Cal. 2005) (holding that class action waivers in consumer contracts of adhesion are unconscionable "in a setting in which disputes between the contracting parties predictably involve small amounts of damages"), abrogated by AT\&T Mobility v. Concepcion, 131 S. Ct. 1740 (2011).

9. AT\&T Mobility, $131 \mathrm{~S}$. Ct. at 1748.

10. 132 S. Ct. 665 (2012). (1987))

11. Id. at 669 (quoting Shearson/Am. Express, Inc. v. McMahon, 482 U.S. 220, 226

12. 482 U.S. 220 (1987) (holding that arbitration provisions in brokerage contracts are enforceable with respect to claims under the Exchange Act); see also Rodriguez de Quijas v. 
interpreted CompuCredit as a statement of FAA supremacy over other federal statutes ${ }^{13}$ setting the stage for a confrontation between the policies of the FAA and the countervailing policies of other federal laws. In particular, those seeking to limit the ability of investors to bring class actions assert that the FAA requires the enforcement of arbitration agreements with class action waivers in all instances. ${ }^{14}$ The broker-dealer Charles Schwab \& Co. (Schwab) recently made this argument in challenging the arbitration rules of the Financial Industry Regulatory Authority (FINRA), the self-regulatory organization (SRO) for broker-dealers. ${ }^{15}$

Virtually all brokerage firms include provisions in their standard-form customer agreements requiring arbitration of customers' disputes in the FINRA forum. ${ }^{16}$ These customers, like other consumers of products and services, may have disputes against their broker-dealers that are more efficiently handled if they are aggregated and indeed may not be feasible to pursue otherwise. ${ }^{17}$ In fall 2011, only a few months after AT\&T Mobility, Schwab amended its customer agreement to require its brokerage customers to waive their rights to bring class actions in court and even to prevent arbitrators from consolidating similar claims submitted by a discrete number of customers. ${ }^{18}$ According to Schwab, "it acted to protect its shareholders and customers from the high costs

Shearson/Am. Express, Inc., 490 U.S. 477 (1989) (holding that arbitration provisions in brokerage contracts are enforceable with respect to claims arising under the Securities Act of 1933).

13. See, e.g., Opinion from Cyril Moscow, Esq., to Office of Chief Counsel, Div. of Corp. Fin., U.S. Sec. and Exch. Comm'n (SEC) (Jan. 12, 2012) (asserting that in CompuCredit the Court was "emphatic that general anti-waiver provisions, such as the one in section 29(a) [of the Exchange Act], are not a barrier to the enforcement of an arbitration provision pursuant to the FAA") (on file with authors).

14. Id. (asserting that $A T \& T$ Mobility makes clear that "class actions are not essential to the vindication of statutory rights").

15. Until mid-2007, the National Association of Securities Dealers, Inc. (NASD) and the New York Stock Exchange (NYSE) ran separate arbitration forums that handled a combined $99 \%$ of all securities arbitrations in the country. On July 30, 2007, NASD and NYSE Regulation, including their respective arbitration forums, consolidated and formed FINRA. See Press Release, Fin. Indus. Regulatory Auth., NASD and NYSE Member Regulation Combine to Form the Financial Industry Regulatory Authority (July 30, 2007), available at http://www.finra.org/Newsroom/NewsReleases/2007/P036329. Today, FINRA's dispute resolution arm administers virtually all arbitrations of securities disputes. See Dispute Resolution, Arbitration and Mediation, http://www.finra.org/Arbitration AndMediation/ (last visited May 30, 2012). Throughout this Article, we will refer to the SRO as NASD for pre-merger events and FINRA for post-merger events.

16. See Jill I. Gross, The End of Mandatory Securities Arbitration?, 30 PACE L. REV. $1174,1180(2010)$.

17. For an extended discussion of the impact of $A T \& T$ Mobility on small claims arbitration for consumers and investors, see Jill Gross, AT\&T Mobility and the Future of Small Claims Arbitration, 41 Sw. U. L. REv. 47 (2012).

18. Complaint and Request for Expedited Hearing IS 1-2, Dept. of Enforcement v. Charles Schwab \& Co., FINRA Disciplinary Proceeding No. 2011029760201 (Feb. 1, 2012), available at http://disciplinaryactions.finra.org/viewdocument.aspx?DocNB=29288. 
and inefficiencies associated with customer class actions." ${ }^{, 19}$ FINRA promptly instituted a disciplinary action against Schwab, charging it with violating FINRA Conduct Rules that barred Schwab's amendment. ${ }^{20}$ In turn, Schwab sued FINRA in federal district court, seeking a declaration that the FAA bars FINRA from enforcing its rules regulating broker-dealers' arbitration agreements. ${ }^{21}$ A magistrate judge dismissed Schwab's complaint for failure to exhaust its administrative remedies without addressing the merits. ${ }^{22}$ Schwab did not appeal the dismissal and indicated that it will not enforce the class action waiver until the FINRA disciplinary action is final. ${ }^{23}$

The typical consumer contract containing a predispute arbitration agreement (PDAA) differs in a number of important ways from a brokerage agreement containing a PDAA. Since McMahon, FINRA, with prodding from the Securities and Exchange Commission (SEC), has engaged in ongoing review and reform of its arbitration rules in order to make the arbitration process fairer for investors. ${ }^{24}$ Under the Exchange Act, FINRA's rules are subject to SEC review and approval: the SEC must approve FINRA's rules, after a public comment period, if it finds they are consistent with the requirements of the Exchange Act and are designed to protect investors and the public interest. ${ }^{25}$ FINRA rules require broker-dealers to alert customers to the inclusion of a PDAA in the customer agreement and to provide information about the arbitration process and, in particular, how it differs from court. ${ }^{26}$

Besides disclosure, FINRA also regulates the arbitration process to a

19. Complaint for Declaratory and Preliminary and Permanent Injunctive Relief $\mathbf{I} 25$, Charles Schwab \& Co. v. Fin. Indus. Regulatory Auth., Inc., 861 F. Supp. 2d 1063 (N.D. Cal. 2012) (No. CV 12-0518).

20. See Complaint and Request for Expedited Hearing, FINRA Disciplinary Proceeding, supra note 18.

21. See Complaint for Declaratory and Preliminary and Permanent Injunctive Relief, supra note 19.

22. Charles Schwab \& Co., 861 F. Supp. 2d 1063. Schwab did not file a Notice of Appeal within the requisite time.

23. Schwab to Hold Off Enforcing Class Action Waivers, Westlaw J. Class Action, June 21, 2012, at 1 (reporting that Schwab spokesperson announced the company "does not have plans to enforce the waiver until the FINRA matter is resolved").

24. See Barbara Black \& Jill I. Gross, Making It Up as They Go Along: The Role of Law in Securities Arbitration, 23 CARDOZO L. Rev. 991, 999-1005 (2002) (describing postMcMahon reforms); Jill I. Gross, McMahon Turns Twenty: The Regulation of Fairness in Securities Arbitration, 76 U. CIN. L. REV. 493, 514-17 (2008) (describing SEC's robust oversight of FINRA's arbitration process and FINRA's frequent reforms of its codes of arbitration procedure).

25. Exchange Act $\S \S 15 \mathrm{~A}(\mathrm{~b})(6), 19(\mathrm{~b})(2), 15$ U.S.C. $\S \S 78 o-3(\mathrm{~b})(6), 78 \mathrm{~s}(\mathrm{~b})(2)(2006)$.

26. The PDAA must be highlighted and immediately preceded by certain information about the arbitration process, in particular how it differs from court. In addition, the customer agreement must include a highlighted statement immediately preceding the signature line that the agreement contains a PDAA and identifying its location in the agreement. FINRA R. 2268(a)-(c) (2011), available at http://finra.complinet.com/en /display/display_main.html?rbid=2403\&element_id=9955. 
degree that commercial arbitration forums may $\operatorname{not}^{27}$ and prohibits firms from placing any condition in a PDAA that limits or contradicts any FINRA rule. ${ }^{28}$ Notably, FINRA does not permit class arbitrations in its forum because it views courts as better equipped to handle complex procedures. ${ }^{29}$ FINRA, however, does permit, under certain circumstances, multiple claimants to combine claims containing common questions of law and fact in the same arbitration. ${ }^{30}$ In contrast to typical consumer agreements like the one at issue in $A T \& T$ Mobility, FINRA does not permit brokerage agreements to contain prohibitions on judicial class actions. ${ }^{31}$ Accordingly, customers that have claims against a brokerage firm suitable for class action treatment are permitted to institute a class action in court, ${ }^{32}$ and the firm cannot enforce the PDAA against a

27. For example, under the FINRA Code of Arbitration Procedure for Customer Disputes, FINRA R. 12000-12905 (2011), available at http://www.finra.org/web/groups /arbitrationmediation/@arbmed/@arbion/documents/arbmed/p117546.pdf] [hereinafter FINRA CUSTOMER CODE], the location of the hearing is determined by the investor's residence (R. 12213), extensive document discovery is permitted, and time-consuming and costly depositions are discouraged (R. 12505-12513), and costly and potentially forumprohibitive dispositive motions are stringently limited (R. 12504). Perhaps most significantly, the forum subsidizes or even waives investors' forum fees. See Capital Markets Regulatory Reform: Strengthening Investor Protection, Enhancing Oversight of Private Pools of Capital, and Creating a National Insurance Office: Hearing Before the H. Comm. on Fin. Serv., 111th Cong. 183 (2009) (testimony of Richard Ketchum, Chairman \& CEO, FINRA) (stating that "FINRA-registered firms pay for most arbitration costs and FINRA waives fees for individuals experiencing financial hardship"); see also FINRA Customer CODE R. 12901.

28. FINRA R. 2268(d)(1).

29. FINRA CUSTOMER CODE R. 12204 (2008).

30. FINRA CUSTOMER CODE R. 12312(a) (if the claims assert any right to relief jointly and severally or the claims arise out of the same transaction or occurrence or series of transactions and occurrences). The Director or the panel may separate the claims into two or more arbitrations. CUSTOMER CODE R. 12312(b). In addition, the Director has the discretion to combine separate but related claims into one arbitration, subject to the panel's reconsideration upon motion of a party. CUSTOMER CODE R. 12314.

31. FINRA R. 2268(d)(3).

32. Customers may bring federal securities fraud class actions under Rule 10b-5, alleging that the broker-dealer made material misstatements to a class of customers, so long as they can plead scienter with the specificity required by the Private Securities Litigation Reform Act of 1995 (PSLRA), Pub. L. No. 104-67, 109 Stat. 737 (codified as amended in scattered sections of 15 U.S.C.). See, e.g., Pearce v. UBS Paine Webber, Inc., No. 3:022409-17, 2003 WL 25518056 (D.S.C. Nov. 4, 2003) (complaint alleging hidden commissions survived motion to dismiss). If plaintiffs' complaint survives the pleading stage, they may encounter difficulty in establishing scienter and materiality. See, e.g., Feinman v. Dean Witter Reynolds, Inc., 84 F.3d 539 (2d Cir. 1996) (alleged misrepresentation that handling charge was related to actual costs was not material).

Alternatively, customers may bring class actions against their broker-dealer on a variety of state law claims, including negligence, breach of contract and breach of fiduciary duty, so long as the claims are not precluded by the Securities Litigation Uniform Standards Act of 1998 (SLUSA), Pub. L. No. 105-353, 112 Stat. 3227 (codified as amended in scattered sections of 15 U.S.C.). Customers have difficulty establishing breach of contract claims because brokerage contracts typically give broker-dealers broad discretion. See, e.g., Appert 
member of the class so long as the class action appears viable. ${ }^{33}$

For example, purchasers of a Schwab mutual fund, the YieldPlus Fund, brought class actions against Charles Schwab entities, including the brokerdealer, alleging that they misrepresented the risk profile and assets of the fund and improperly changed the fund's investment policies. Plaintiffs alleged that the defendants issued, underwrote and distributed the shares in violation of federal securities and state laws. ${ }^{34}$ Because a number of the investors had brokerage accounts with Schwab, if the Schwab arbitration language had been in effect and were enforceable, they would have been required to arbitrate individual claims. At least for investors whose damages were small, this would not be an optimal outcome. In approving the class action settlement, the court noted that the resolution offered "substantial recoveries" that "will provide real benefits" to the investors. ${ }^{35}$ The average estimated settlement payment in the federal action was $\$ 881,{ }^{36}$ an amount that would not have made individual arbitration feasible.

Schwab is not the only firm that has attempted, in the wake of $A T \& T$ Mobility, to limit investors' access to courts. In early 2012, Carlyle Group LP amended a registration statement it filed with the SEC for an initial public offering of its limited partnership units to disclose that the Carlyle partnership agreement would require investors to arbitrate all disputes with the LP, including federal securities claims. It also would provide that investors may only bring claims in their individual capacities, arbitrators could not consolidate claims, and the proceedings, including any awards, were confidential. ${ }^{37}$ Carlyle stated that it included the provision because it believed "that arbitrating claims would be more efficient, cost effective and beneficial to

v. Morgan Stanley, 673 F.3d 609 (7th Cir. 2012) (contract did not require that handling charge be tied to actual costs); Green v. Ameritrade, Inc., No. A-05-651, 2007 WL 1599708 (Neb. Ct. App. June 5, 2007) (summary judgment for defendant on claim it failed to provide "real time" quotes on website).

33. FINRA CUSTOMER CODE R. 12204(d).

34. In re Charles Schwab Sec. Litig., 257 F.R.D. 534 (N.D. Cal. 2009).

35. In re Charles Schwab Sec. Litig., No. C08-01510 WHA, 2011 WL 1481424, at*5 (N.D. Cal. Apr. 19, 2011).

36. Id. It has been suggested that one possible impetus for Schwab's insertion of a class action waiver in its customer PDAA was its experience with the YieldPlus class action litigation and collateral arbitrations. See Richard P. Ryder, Class Action Waivers and Arbitration Agreements, SeCURITIES ARBITRATION COMMENTATOR 1, Oct. 2011 (reporting cost to Schwab of Schwab Yield Plus class action settlement, which dwarfed the cost of the arbitrations and the small claims resolved in-house).

37. The Carlyle Group L.P., Amendment No. 2 to Form S-1 Registration StATEMENT PURSUANT TO THE SECURITIES ACT OF 1933, at 287 (Jan. 10, 2012), available at http://www.sec.gov/Archives/edgar/data/1527166/000095012312000638/w83442a2sv1 za.ht m; see Steven M. Davidoff, Carlyle Readies an Unfriendly I.P.O. for Shareholders, N.Y. TiMES DEALBook (Jan. 18, 2012, 3:19 PM), http://dealbook.nytimes.com/2012/01/18/ carlyle-readies-an-unfriendly-i-p-o-for-shareholders (stating that the provisions essentially eliminate the investors' ability to sue the board). 
our unit holders." 38 The SEC's Division of Corporation Finance (Corp Fin), which has a longstanding position that arbitration provisions in publicly-traded issuer's governance documents violate federal securities laws, reacted with displeasure, ${ }^{39}$ as did several members of Congress. ${ }^{40}$ Carlyle subsequently announced that it was dropping the arbitration provision, so as not to delay the offering. ${ }^{41}$

As a third example of recent attempts to limit investors' access to courts, in spring 2012, shareholders sought to include in the proxy statements of four publicly-traded corporations identical proposals to amend the bylaws to require arbitration of all shareholders' claims, including federal securities claims, and to bar class actions. ${ }^{42}$ The proponents explained that adoption of the proposal would be beneficial because "[1]awyer driven class actions impose large burdens on corporations without meaningful benefits to shareholders.... Requiring arbitration on an individual basis should reduce such abuses." Pfizer Inc. ${ }^{44}$ and Gannett Co. ${ }^{45}$ sought and obtained no-action letters from the SEC to keep the proposals off their proxy statements. ${ }^{46}$ The SEC's Corp Fin, in the cryptic language typical of no-action responses, "note[d] that there appears to be some basis for your view that implementation of the proposal would cause the company to violate the federal securities laws." ${ }^{47}$ The proposal also appeared in proxy statements of Google ${ }^{48}$ and Frontier Communications ${ }^{49}$

38. Yin Wilczek, Carlyle Drops Mandatory Arbitration Clause; SEC Says Inclusion Would Have Delayed IPO, BloOMBERg BNA SeCURITIES LAW DAILY, Feb. 6, 2012.

39. Letter from the SEC Div. of Corp. Fin. to Jeffrey W. Ferguson, Gen. Counsel, The Carlyle Group L.P. (Feb. 3, 2012) (on file with authors) (stating that Corp Fin "does not anticipate that it will exercise its delegated authority to accelerate the effective date of your registration statement if your limited partnership agreement includes such a provision....").

40. Letter from Senators Al Franken, Richard Blumenthal, and Robert Menendez to SEC Chairman Mary Schapiro (Feb. 3, 2012) (on file with authors) (urging the SEC to maintain its policy of opposing provisions mandating arbitration of shareholder disputes in governance documents of public companies).

41. See Wilczek, supra note 38.

42. The proposed amendment would not apply to appraisal proceedings and large individual claims (over \$3 million) and would only apply prospectively. See, e.g., FrontIER Communications Corp., Schedule 14A: Proxy Statement Pursuant to Section 14(A) OF THE SECURITIES EXCHANGE ACT OF 1934, at 44 (Mar. 26, 2012), available at http://www.sec.gov/Archives/edgar/data/20520/000093041312001787/c68718_def14a.htm\# c68718_stockholder2.

43. Id.

44. Pfizer Inc., SEC No-Action Letter, 2012 WL 587597 (Feb. 22, 2012).

45. Gannett Co., Inc., SEC No-Action Letter, 2011 WL 6859124 (Feb. 22, 2012).

46. The proponents for all four proposals were represented by a Michigan attorney (Cyril Moscow), who is an adjunct professor at the University of Michigan Law School, and Professor of Law Adam Pritchard provided an opinion on the legality of the provision under Delaware law and the inapplicability of Exchange Act $\$ 29$ (a).

47. Pfizer Inc., SEC No-Action Letter, 2012 WL 587597 (Feb. 22, 2012).

48. Google Inc., Schedule 14A: Proxy Statement Pursuant to Section 14(a) of THE SECURITIES EXCHANGE ACT OF 1934, at 103 (May 9, 2012), available at 
without management's endorsement and failed to garner substantial shareholder support. $^{50}$

Several influential academics contend that $A T \& T$ Mobility and CompuCredit permit public companies to prohibit investors' aggregation of claims in customer agreements and shareholder documents. ${ }^{51}$ Although the Carlyle and shareholder proposals mentioned above are now off the table and thus present no controversy ripe for adjudication, the issue is certainly not dead, and it is likely that other issuers will brave public criticism and challenge the SEC's opposition to class waivers at some time in the future.

Meanwhile, the Schwab-FINRA controversy seems unlikely to settle. There is no question that Schwab has agreements with its customers that require arbitration of customers' disputes, the terms of these agreements are regulated pursuant to FINRA rules, and FINRA rules are, in turn, subject to SEC approval under the Exchange Act. ${ }^{52}$ FINRA wants to uphold its rules, and Schwab appears determined to fight FINRA, perhaps ultimately to the Supreme Court. ${ }^{53}$ Thus, the Schwab dispute presents a concrete conflict ${ }^{54}$ between the

http://sec.gov/Archives/edgar/data/1288776/000119312512222158/d320628ddef14a.htm.

49. See Frontier Communications Corp., Schedule 14A Proxy Statement, supra note 42 .

50. Frontier Communications CorP., CurRent RePORT ON Form 8-K item 5.07 (May 14, 2012), available at http://www.sec.gov/Archives/edgar/data/20520/000002052 012000043/votingresults.htm; GOOGLE INC., CURRENT REPORT ON FORM 8-K, item 5.07 (June 26, 2012), available at http://www.sec.gov/Archives/edgar/data/1288776/0001193125122 83173/d357265d8k.htm.

51. Professor Adam C. Pritchard, University of Michigan Law School, has stated that the SEC's no-action position in Gannett and Pfizer ignores Supreme Court precedent. See The Curious Case of Carlyle ... and Efforts to Shut Down Investor Access to Courts, SECURITIES DoCKET (Apr. 18, 2012), https://www.brighttalk.com/webcast/513/44957. Professor John C. Coffee, Jr., Columbia Law School, states that "opponents must face the sad fact that the battle has already been lost with respect to Carlyle's ability to limit investors to suits based on "'negative value"" claims." John C. Coffee, Jr., The Death of Stockholder Litigation?, NAT'L L.J. (Feb. 13, 2012), http://www.law.com/jsp/nlj/PubArticleNLJ.jsp? $\mathrm{id}=1202541959250$. Professor Hal Scott, Harvard Law School, states that investors should not be "deprived of the opportunity to decide upon the dispute-resolution procedure they preferred." Hal Scott \& Leslie N. Silverman, The Alternative to Shareholder Class Actions, Wall ST. J. OnLine (Apr. 1, 2012, 5:48 PM), http://online.wsj.com/article/SB100014 24052702303816504577312373860495762.html.

52. In contrast, in the Carlyle and shareholder proposal disputes, there are additional complex and unresolved legal questions, principally whether provisions in corporate governance documents constitute arbitration agreements under the FAA and whether they are enforceable under applicable state corporate law. See Barbara Black, Arbitration of Investors' Claims Against Issuers: An Idea Whose Time Has Come?, 75 LAW \& CONTEMP. ProBs. 107 (2012); Barbara Black, Eliminating Securities Fraud Class Actions Under the Radar, 2009 Colum. Bus. L. Rev. 802.

53. Appeals from FINRA disciplinary actions are heard by the National Adjudicatory Council. See FINRA CODE OF PROCEDURE R. 9310-13. An aggrieved person may then appeal to the SEC, or the SEC may review the matter on its own motion. See Exchange Act $\S$ 19(d), 15 U.S.C. $§ 78$ s(d) (2006); FINRA, CODE OF PROCEDURE R. 9370. A person aggrieved by an SEC final order may obtain review in the Circuit Court of Appeals in which he resides 
FAA and the Exchange Act that is currently being litigated by motivated parties.

While Schwab challenges in particular FINRA's authority to bar the class action waiver provision, the dispute has broader implications. Round two of AT\&T Mobility is likely to involve other conflicts between the FAA and federal regulatory policy designed to protect certain segments of the public. ${ }^{55}$ For example, in the Dodd-Frank Wall Street Reform and Consumer Protection Act (Dodd-Frank) ${ }^{56}$ Congress created the Consumer Financial Protection Bureau (CFPB) ${ }^{57}$ with broad authority to administer, enforce and implement the provisions of federal consumer financial law. ${ }^{58}$ After completing a study on the use of PDAAs in connection with the offering or providing of consumer financial products or services, ${ }^{59}$ the CFPB may adopt rules to "prohibit or impose conditions or limitations" on the use of PDAAs if it finds that such a rule is "in the public interest and for the protection of consumers." 60 The CFPB has not yet completed the requisite study, ${ }^{61}$ but if it ultimately determines to move forward with rulemaking to limit or prohibit use of PDAAs in consumer financial services agreements, we can expect industry challenges that may ultimately come before the courts.

Does the FAA limit the ability of federal regulators acting pursuant to congressional authority to impose conditions and limitations on the use of arbitration provisions in order to ensure fairness? In this Article, we focus on the federal securities laws and argue that, when in direct conflict, the Exchange Act's specific and more recent regulations designed to protect investors supplant the FAA's general (though powerful) mandate supporting the

or has his principal place of business or to the District of Columbia Court of Appeals. See Exchange Act $\S 25(a), 15$ U.S.C. $\S 78 y$. FINRA, acting in its adjudicative capacity as a lower tribunal subject to SEC plenary review of its disciplinary decisions, is not an “aggrieved person.” NASD, Inc. v. SEC, 431 F.3d 803 (D.C. Cir. 2005). A court of appeals decision is then subject to review by the Supreme Court upon certiorari or certification. 28 U.S.C. $\$ 1254$ (2006).

54. While some have characterized the issue as one of "preemption," we avoid that term here as it applies to conflicts between federal and state law, not conflicts between two federal laws.

55. Paul F. Kirgis, The Roberts Court vs. the Regulators: Surveying Arbitration's Next Battleground, 10 THE MAYHEW-Hite RePORT ON Dispute Resolution AND THE CourTs, Issue 3, Mar. 2012, available at http://moritzlaw.osu.edu/epub/mayhew-hite/report/volume10/issue-3/.

56. Dodd-Frank Wall Street Reform and Consumer Protection Act, Pub. L. No. 111203, 124 Stat. 1376 (2010) (codified in scattered sections of U.S.C.).

57. Id. $\S 1011,12$ U.S.C. $\S 5491$.

58. Id. $\$ 1022(\mathrm{a}), 12$ U.S.C. $\$ 5512$.

59. Id. $\$ 1028($ a), 12 U.S.C. $\$ 5518$.

60. Id. $\$ 1028(\mathrm{~b}), 12$ U.S.C. $\$ 5518$.

61. Request for Information Regarding Scope, Methods and Data Sources for Conducting Study of Pre-Dispute Arbitration Agreements, 77 Fed. Reg. 25148 (Apr. 27, 2012). 
enforceability of arbitration agreements.

This Article proceeds in four parts. In Part I, we summarize current Supreme Court FAA jurisprudence that establishes a strong national proarbitration policy and discuss in detail the AT\&T Mobility decision preempting a state judicial doctrine declaring class action waivers in an arbitration agreement unconscionable. In Part II, we describe the Exchange Act's regulation of arbitration involving broker-dealers, including its anti-waiver provision barring any condition that forces investors to waive compliance with any part of the Act, its rules and SRO rules, and its authority delegated to the SEC and FINRA to regulate the content of arbitration clauses in brokerdealer/customer contracts. Part III details the current litigation and regulatory dispute between Schwab and FINRA over Schwab's inclusion of a class action waiver in its customer agreement. In Part IV, we demonstrate that Schwab's conduct poses a clear conflict between the FAA and the Exchange Act. We argue that courts should resolve this conflict by applying the Exchange Act over the FAA through the long-standing doctrine of implied repeal, additional well-accepted canons of statutory construction, as well as current Exchange Act and FAA jurisprudence.

\section{THE FAA PREEMPTION DOCTRINE}

Congress enacted the FAA in 1925 "to overrule the judiciary's longstanding refusal to enforce agreements to arbitrate." ${ }^{, 2}$ Its primary substantive provision, § 2-which declares that agreements to arbitrate are "valid, irrevocable, and enforceable, save upon such grounds as exist at law or in equity for the revocation of any contract" $" 63$ - "embodies the national policy favoring arbitration and places arbitration agreements on equal footing with all other contracts." ${ }^{\prime 4}$ Thus, the FAA's "principal purpose" was to "require[] courts to enforce privately negotiated agreements to arbitrate, like other contracts, in accordance with their terms." 65

The Court has repeatedly held that the FAA "creates a body of federal substantive law of arbitrability, applicable to any arbitration agreement within the coverage of the Act." ${ }^{66}$ In the past four decades, the Court's FAA

62. Volt Info. Scis., Inc. v. Bd. of Trs. of Leland Stanford Junior Univ., 489 U.S. 468, 478 (1989); see also Buckeye Check Cashing, Inc. v. Cardegna, 546 U.S. 440, 443 (2006).

63. 9 U.S.C. $\S 2$ (2006). This latter phrase of $\S 2$ is known as the FAA's "savings clause."

64. Buckeye, 546 U.S. at 443; see also Moses H. Cone Memorial Hosp. v. Mercury Constr. Corp., 460 U.S. 1, 24 (1983) (recognizing a "liberal federal policy favoring arbitration agreements"); Mitsubishi Motors Corp. v. Soler Chrysler-Plymouth, Inc., 473 U.S. 614 (1985).

65. Volt Info Scis., Inc., 489 U.S. at 478.

66. See, e.g., Moses H. Cone, 460 U.S. at 24. The Court defined arbitrability in this context as "the duty to honor an agreement to arbitrate." Id. at 25 n.32. 
jurisprudence has catapulted the FAA to super-status: it governs virtually every arbitration clause arising out of a commercial transaction, ${ }^{67}$ applies in both state and federal court, ${ }^{68}$ compels the arbitrability of federal statutory claims, ${ }^{69}$ permits arbitrators to rule on the unconscionability of the arbitration clause, ${ }^{70}$ and preempts any state law that "actually conflicts with federal law-that is, to the extent that it "stands as an obstacle to the accomplishment and execution of the full purposes and objectives of Congress.",71

Under FAA obstacle preemption, the Supreme Court has rebuffed state law-based defenses to the enforcement of arbitration agreements to the extent those defenses single out arbitration agreements for hostile treatment. ${ }^{72}$ Thus, the Court has held that the FAA preempts state statutes that prohibit the arbitration of a particular type of claim $^{73}$ and state judicial rules that display

67. By its terms, the FAA governs agreements to arbitrate involving "transactions in commerce." 9 U.S.C. $\$ 2$ (2006). The Supreme Court has interpreted this phrase very broadly to include any transaction that in fact involves interstate commerce, even if the parties did not anticipate an interstate impact. See Allied-Bruce Terminix Cos. v. Dobson, 513 U.S. 265, 273-74, 281 (1995) (interpreting the reach of the FAA broadly to all transactions "involving commerce" and stating that "involving' is broad and is indeed the functional equivalent of 'affecting'"); Howsam v. Dean Witter Reynolds, Inc., 537 U.S. 79 (2002) (applying FAA to securities arbitrations); Citizens Bank v. Alafabco, Inc., 539 U.S. 52 (2003) (applying FAA to debt restructuring agreements as "involving commerce").

68. See Southland Corp. v. Keating, 465 U.S. 1, 12 (1984) ("The statements of the Court in Prima Paint that the Arbitration Act was an exercise of the Commerce Clause power clearly implied that the substantive rules of the Act were to apply in state as well as federal courts.").

69. CompuCredit Corp. v. Greenwood, 132 S. Ct. 665 (2012).

70. Rent-A-Center, West, Inc. v. Jackson, 130 S. Ct. 2772 (2010).

71. Volt Info. Scis., Inc., 489 U.S. at 478 (quoting Hines v. Davidowitz, 312 U.S. 52, 67 (1941)); see Prima Paint Corp. v. Flood \& Conklin Mfg. Co., 388 U.S. 395 (1967); Moses H. Cone, 460 U.S. 1; see also Perry v. Thomas, 482 U.S. 483 (1987) (preempting California statute requiring wage collection actions to be resolved in court). The Supreme Court has explained that it will find a state law preempted by a congressional act when: (1) the federal law expressly provides it displaces state law (express preemption); (2) Congress intends the federal law in an area to "occupy the field" (field preemption); (3) it is impossible for a party to comply with both the state and federal law (impossibility preemption); and (4) the challenged state law stands as an obstacle to the accomplishment and execution of the full purposes and objectives of Congress (obstacle preemption). See Crosby v. Nat'l Foreign Trade Council, 530 U.S. 363, 372-73 (2000) (internal citations and quotations omitted). Impossibility and obstacle preemption are both subcategories of conflict preemption. Id. See generally Caleb Nelson, Preemption, 86 VA. L. REV. 225, 228 (2000) (describing preemption categories).

72. None of these decisions preempt a state arbitration law-laws that primarily address arbitration procedures and award enforcement, and almost uniformly further a proarbitration policy. Rather, the Court has preempted state laws on non-arbitration matters that contain "lingering anti-arbitration sentiment." Stephen L. Hayford \& Alan R. Palmiter, Arbitration Federalism: A State Role in Commercial Arbitration, 54 FLA. L. REV. 175, 195 (2002).

73. See Southland, 465 U.S. at 12 (preempting provision of the California Franchise Investment Law that required judicial, not arbitral, resolution of claims brought under the statute); Preston v. Ferrer, 552 U.S. 346 (2008) (preempting California law granting 
vestiges of the ancient judicial hostility to arbitration. ${ }^{74}$ Similarly, the FAA preempts state statutes that invalidate arbitration agreements on grounds different than those that invalidate other contracts. ${ }^{75}$ For example, in Cassarotto, which arose out of a franchisor-franchisee dispute, the Court held that the FAA preempted a Montana statute requiring that, to be enforceable, an arbitration agreement must include very specific disclosures that it is subject to arbitration and in a very specific way ("typed in underlined capital letters on the first page of the contract"). ${ }^{76}$ Because this pro-consumer notice requirement applied only to arbitration agreements and not contracts generally, the Court concluded that the law singled out arbitration agreements for hostile treatment and was displaced by the FAA. ${ }^{77}$

Most recently, in AT\&T Mobility, LLC v. Concepcion, ${ }^{78}$ the Court held that the FAA preempted a state law that on its face was not anti-arbitration but was being applied by lower courts in a manner that de facto interfered with arbitration. In its consumer cellular phone service contracts, AT\&T Mobility, LLC (AT\&T) included a PDAA which, inter alia, prohibited plaintiffs from bringing class action arbitrations, instead requiring claims to be arbitrated on an individual basis. In 2006, the Concepcions sued AT\&T in district court, alleging that AT\&T's practice of charging sales tax on a phone advertised as "free" was fraudulent. ${ }^{79}$ In December 2006, after the Concepcions filed their claim, AT\&T revised the arbitration agreement to provide that AT\&T would pay a customer $\$ 7,500$ and twice its attorney's fees if an arbitrator found in favor of a California customer on the merits of a customer dispute and awarded

exclusive jurisdiction to Labor Commissioner to decide disputes arising under the Talent Agencies Act).

74. See Mastrobuono v. Shearson Lehman Hutton, 514 U.S. 52 (1995) (preempting New York law precluding arbitrators from awarding punitive damages); Buckeye Check Cashing, Inc. v. Cardegna, 546 U.S. 440 (2006) (preempting Florida judicial rule that precluded arbitrators from deciding the legality of an allegedly usurious contract containing an arbitration agreement); Marmet Health Care Ctr., Inc. v. Brown, 132 S. Ct. 1201 (2012) (preempting West Virginia Supreme Court rule voiding as against public policy pre-dispute arbitration clauses in nursing home contracts with respect to negligence claims); Nitro-Lift Tech., L.L.C. v. Howard, 133 S. Ct. 500 (2012) (preempting Oklahoma Supreme Court rule that a court, not an arbitrator, determines the validity of a covenant not to compete in a contract containing an arbitration clause). In contrast, the FAA does not preempt a state arbitration statute that merely dictates the order of proceedings with respect to an arbitration and related third-party litigation, but does not regulate the viability or scope of the arbitration agreement itself. Volt Info. Scis., Inc., 489 U.S. 468.

75. See Allied-Bruce Terminix Cos. v. Dobson, 513 U.S. 265, 273-74, 281 (1995) (preempting Alabama statute invalidating pre-dispute arbitration agreements in consumer contracts); Doctor's Assocs., Inc. v. Casarotto, 517 U.S. 681, 685 (1996) (preempting Montana statute requiring specific type of notice in contract containing arbitration clause).

76. Casarotto, 517 U.S. at 684 (quoting MonT. CodE ANN. § 27-5-114(4) (1995)).

77. Id. at 687.

78. 131 S. Ct. 1740 (2011).

79. Laster v. AT\&T Mobility LLC, 584 F.3d 849, 853 (9th Cir. 2009). The Concepcions' case was consolidated with Laster in September 2006. 
more than the last AT\&T settlement offer. ${ }^{80}$ Two years later, after the Concepcions' case was consolidated with a putative class action alleging, inter alia, identical claims of false advertising and fraud, AT\&T moved to compel arbitration under the revised agreement. ${ }^{81}$

The district court refused to enforce the arbitration agreement in light of Discover Bank v. Superior Court. ${ }^{82}$ In Discover Bank, the California Supreme Court applied the state's general unconscionability law ${ }^{83}$ to class-action waivers in arbitration agreements and held:

[W] hen the waiver is found in a consumer contract of adhesion in a setting in which disputes between the contracting parties predictably involve small amounts of damages, and when it is alleged that the party with the superior bargaining power has carried out a scheme to deliberately cheat large numbers of consumers out of individually small sums of money, then ... the waiver becomes in practice the exemption of the party "from responsibility for [its] own fraud, or willful injury to the person or property of another." Under these circumstances, such waivers are unconscionable under California law and should not be enforced. ${ }^{84}$

The district court in $A T \& T$ Mobility concluded that the class action waiver at issue was unconscionable because it had a deterrent effect on class actions and the efficient resolution of third-party claims. ${ }^{85}$ The Ninth Circuit affirmed and AT\&T sought review in the Supreme Court. ${ }^{86}$

In a 5-4 majority decision authored by Justice Scalia, the Court (joined by Justices Roberts, Kennedy, Thomas and Alito) held that the FAA preempts California's Discover Bank interpretation of the state's unconscionability rule, which, as the majority defined the rule, "classif[ied] most collective-arbitration waivers in consumer contracts as unconscionable." 87 Even though, as the dissent noted, ${ }^{88}$ the Discover Bank rule applied equally to class action waivers

80. Id.

81. Id.

82. 113 P.3d 1100 (Cal. 2005).

83. Under California law, a court may refuse to enforce a contract that it finds " to have been unconscionable at the time it was made,"” or it may " "limit the application of any unconscionable clause." AT\&T Mobility, $131 \mathrm{~S}$. Ct. at 1746 (quoting CAL. CIV. CodE ANN. $\S 1670.5$ (a) (1985)). "A finding of unconscionability requires a 'procedural' and a 'substantive' element, the former focusing on 'oppression' or 'surprise' due to unequal bargaining power, the latter on 'overly harsh' or 'one-sided' results." Id. (citations omitted).

84. 113 P.3d at 1109-10.

85. Laster v. T-Mobile USA, Inc., No. 05CV1167 DMS (AJB), 2008 WL 5216255, at *14 (S.D. Cal. Aug. 11, 2008).

86. Laster, 584 F.3d at 853-69.

87. AT\&T Mobility, $131 \mathrm{~S}$. Ct. at 1746.

88. In dissent, Justice Breyer (joined by Justices Ginsburg, Sotomayor and Kagan) argued that California's Discover Bank rule "represents the 'application of a more general [unconscionability] principle." Id. at 1757 (Breyer, J., dissenting) (citing Gentry v. Superior Ct., 42 Cal. 4th 443, 457 (2007)). The dissent contended that, because the Discover Bank rule is a rule of state law applicable to all contracts and not just arbitration agreements, it 
in all dispute resolution contracts, the majority was persuaded by research demonstrating that state courts had become more likely to find an arbitration agreement unconscionable as opposed to other contracts. ${ }^{89}$ Thus, the Discover Bank rule was preempted because "[r]equiring the availability of classwide arbitration interferes with fundamental attributes of arbitration and thus creates a scheme inconsistent with the FAA." 90

Justice Scalia's majority opinion reasoned that the Discover Bank rule interfered with arbitration because, while California's "rule does not require class-wide arbitration, it allows any party to a consumer contract to demand it ex post," thus defeating the purposes of the FAA. ${ }^{91}$ The Court discussed three characteristics of class arbitration that it concluded defeat the purposes of the FAA and hinder the flexible party-driven process of arbitration: (1) sacrifice of informality and speed; (2) a requisite increase in procedural formality; and (3) an increase in risks to defendants in the lack of judicial review. ${ }^{92}$ Exhibiting its distrust of class arbitration that also appeared in the Court's 2010 decision in Stolt-Nielsen S.A. v. AnimalFeeds Int'l Corp,$^{93}$ the Court characterized class arbitration as not arbitration at all within the meaning of the FAA, but a process that alters the fundamental attributes of arbitration. ${ }^{94}$

Criticizing the majority's conclusion that class arbitration is lacking the "fundamental attribute[s]" of arbitration within the meaning of the FAA, the dissent argued that class proceedings are necessary to protect against small-

falls within the savings clause and the FAA should not preempt it. Id.

89. AT\&T Mobility, $131 \mathrm{~S}$. Ct. at 1747.

90. Id. at 1748 .

91. Id. at 1750 .

92. Id. at 1751-52. Although the majority expressly included the procedural expediency of arbitration as one of the FAA's purposes with which the Discover Bank rule interferes, the dissent referred to the Court's Dean Witter decision in which it specifically "reject[s] the suggestion that the overriding goal of the [FAA] was to promote the expeditious resolution of claims." Id. at 1758 (Breyer, J., dissenting) (citing Dean Witter Reynolds Inc. v. Byrd, 470 U.S. 213, 221 (1985)).

93. 130 S. Ct. 1758 (2010) (arbitrators cannot construe silence in an arbitration agreement as consent to class arbitration).

94. Justice Thomas "reluctantly join[ed]" the majority, but wrote "separately to explain how [he] would find [a] limit" on contract defenses permitted by FAA $\S 2$. Id. at 1753-54 (Thomas, J., concurring). In his concurring opinion, Justice Thomas reasoned that the savings clause of the FAA permits exceptions to the enforceability of arbitration agreements only for defenses that "relate[] to the making of the [arbitration] agreement." Id. at 1754-55 (quoting FAA § 4). Because the Discover Bank rule did not relate to the formation of the arbitration agreement within the meaning of FAA $\S \S 2$ and 4, Justice Thomas concluded that it was preempted by the FAA. Justice Thomas may have felt compelled to articulate his reading of the savings clause because, in past preemption cases, he dissented based on his view, first articulated in Allied-Bruce Terminix Cos. v. Dobson, 513 U.S. 265, 273-74, 281 (1995) (Thomas, J., dissenting), that the FAA does not apply in state courts. Since this case came up through the federal courts, that basis of dissent did not apply. 
value claims falling through the cracks of the legal system. ${ }^{95}$ Justice Breyer opined that barring class arbitration and forcing lower courts to enforce adhesive class arbitration waivers would "have the effect of depriving claimants of their claims." 96 Justice Scalia responded to the dissent's concern by stating that "States cannot require a procedure that is inconsistent with the FAA, even if it is desirable for unrelated reasons." 97

Thus, under $A T \& T$ Mobility, the FAA preempts state laws that automatically void an arbitration agreement containing a class action waiver. $A T \& T$ Mobility does not, however, stand for the proposition that the FAA displaces federal laws that regulate certain types of arbitration agreements to, inter alia, ban class action waivers. In the next Part, we describe those provisions of the federal securities laws that regulate arbitration between customers and their brokerage firms.

\section{SEC AND FINRA REgUlATION OF SECURITIES ARBITRATION PURSUANT TO THE EXCHANGE ACT}

In adopting the Exchange Act in 1934 and in subsequent amendments, ${ }^{98}$ Congress recognized that securities transactions are "affected with a national public interest which makes it necessary to provide for regulation and control of [securities] transactions and of practices and matters related thereto." "99 "A basic factor underlying the enactment of the Federal securities acts was recognition of the intricate nature and high liquidity of securities and of the

95. AT\&T Mobility, 131 S. Ct. at 1760-61 (Breyer, J., dissenting).

96. Id. at 1761. Justice Breyer asked the Concepcion majority, "[w] hat rational lawyer would have signed on to represent the Concepcions in litigation for the possibility of fees stemming from a \$30.22 claim?” Id. at 1761 (citing Carnegie v. Household Int'1, Inc., 376 F.3d 656, 661 (7th Cir. 2004) (“... [o]nly a lunatic or a fanatic sues for \$30.”)). In doing so, he cited an appellate court which recognized previously the "realistic alternative to a class action is not 17 million individual suits, but zero individual suits ..." Id. at 1761 . Academic commentary that followed the decision harshly criticized it as the death knell for consumers' ability to pursue small dollar value claims. See, e.g., Sarah Cole, On Babies and Bathwater: The Arbitration Fairness Act and the Supreme Court's Recent Arbitration Jurisprudence, 48 Hous. L. REV. 457 (2011); Jean Sternlight, Tsunami: AT\&T Mobility v. Concepcion Impedes Access to Justice, 90 OR. L. REV. 703, 723 (2012).

97. AT\&T Mobility, 131 S. Ct. at 1753.

98. In enacting the Exchange Act in 1934, Congress determined to rely, to a great extent, on industry self-regulation and designated national securities exchanges as SROs because they were already in existence as organizations that regulated their members. In 1938, Congress amended the Exchange Act to authorize the registration of national securities associations to regulate brokers in the over-the-counter market. FINRA is the only registered national securities association. In 1975, Congress amended the Exchange Act to give the SEC broad new powers over the SROs, including the power to review all their proposed rules and to require them to adopt, change or repeal any rules. See generally NoRMAN S. Poser \& JAMES A. FANTO, BROKER-DEALER LAW AND REGULATION $§ 4$ (4th ed. 2007).

99. Exchange Act $\S 2$, 15 U.S.C. $§ 78$ b (2006 \& Supp. V 2011). 
corresponding duties necessarily assumed by those who deal in them."100 The broker-dealer industry is highly regulated "because of its economic importance" and "the possibility of investor abuse." 101

The importance of investor protection and fairness is pervasive throughout the Exchange Act and in the regulation of broker-dealers. Three Exchange Act provisions give the SEC or FINRA authority to regulate PDAAs between customers and broker-dealers. Section 15A gives FINRA broad authority to regulate the broker-dealer industry, subject to SEC oversight. Two other provisions address agreements: $\S 29$ (a), which prohibits waivers of statutory or regulatory compliance, and $\S 15(\mathrm{o})$, which gives the SEC the power to ban PDAAs with respect to federal securities and SRO claims. We discuss below each of these provisions.

\section{A. Exchange Act $\$ 15 A$}

Congress assigned the front-line authority for regulating the broker-dealer industry to SROs, including securities exchanges and national securities associations. ${ }^{102}$ Industry self-regulation is "an essential and officially sanctioned part of the regulatory pattern." 103 Indeed, "it is doubtful whether any regulated industry has been allowed to regulate itself to the degree the securities industry has." 104 FINRA is registered with the SEC as a national securities association under Exchange Act $\S 15 \mathrm{~A}^{105}$ and is the largest independent regulator for all securities firms doing business in the United States. ${ }^{106}$ Congress also adopted a comprehensive system of SEC oversight over the SROs, in order that self-regulation could accomplish its purpose of protecting investors and serving the public interest. ${ }^{107}$ The SEC exercises oversight of FINRA's activities, including operation of its arbitration forum, ${ }^{108}$ the largest dispute resolution forum in the securities industry. ${ }^{109}$

As a national securities association, FINRA's raison d'etre is to carry out the statutory purposes and to enforce compliance by its members and associated persons with the provisions of the Exchange Act and its regulations

100. U.S. Sec. and Exch. Comm'n, Report of Special Study of Securities MARKETS, H.R. DoC. No. 88-95, pt. 1, at 6 (1963) [hereinafter "SEC SPECIAL STUDY"].

101. POSER \& FANTO, supra note $98, \S 1.01$.

102. Exchange Act $\S \S 6,15 \mathrm{~A}, 15$ U.S.C. $\$ \S 78 f, 78 o-3$ (2006 \& Supp. V 2011).

103. SEC SPECIAL STUDY, supra note 100, pt. 4, at 501.

104. POSER \& FANTO, supra note $98, \S 4.01$.

105. Exchange Act $\S 15$ A, 15 U.S.C. $\$ 78 o-3$.

106. About the Financial Industry Regulatory Authority, FINANCIAL INDUSTRY REgUlATORY AuthORITY, http://www finra.org/AboutFINRA/ (last visited Dec. 30, 2012).

107. POSER \& FANTO, supra note $98, \S 4.04[\mathrm{~A}]$.

108. Exchange Act $\S 19,15$ U.S.C. $§ 78$ s (2006 \& Supp. V 2011).

109. Arbitration \& Mediation, FinANCIAL INDUSTRY REgUlATORY AUTHORITY, http://www.finra.org/ArbitrationAndMediation/index.htm (last visited Dec. 30, 2012). 
as well as FINRA's own rules. ${ }^{110}$ The Exchange Act requires FINRA to adopt rules that may be designed for a variety of purposes, ranging from preventing "fraudulent and manipulative acts and practices" to promoting "just and equitable principles of trade" and "in general, [protecting] investors and the public interest." "111 FINRA must file proposed rule changes with the SEC, and the SEC must publish notice and provide interested persons an opportunity to comment on the proposal. ${ }^{112}$ With only minor exceptions, no proposed rule change takes effect unless it is approved by the SEC, upon a finding that it is "consistent" with the requirements of the Exchange Act and the applicable regulations. ${ }^{113}$ In addition, the SEC may, on its own initiative, amend FINRA's rules as it deems "necessary or appropriate ... in furtherance of the purposes of the Act," "114 thus giving the SEC further persuasive power to prod FINRA into action if necessary.

We discuss in Part III.D the specific FINRA rules at issue in the dispute between FINRA and Schwab. ${ }^{115}$ These rules are the product of active engagement by both the SEC and FINRA in regulating the SRO securities arbitration process. At least since the mid-1970s the SEC has asserted the need for a nationwide investor dispute resolution system to handle small claims and has worked with the SROs, industry representatives and investor groups to develop arbitration rules to achieve this result. ${ }^{116}$ Indeed, in McMahon, the SEC filed an amicus brief in support of SRO arbitration. ${ }^{117}$ The SEC intensified its efforts after McMahon, when SRO arbitration became the principal forum for resolving customers' disputes with their brokers. ${ }^{118}$

110. Exchange Act $\S 15 A(b)(2), 15$ U.S.C. $\S 78 o-3$ (2006 \& Supp. V 2011).

111. Id. $\S 15 \mathrm{~A}(\mathrm{~b})(6), 15$ U.S.C. $\S 78 o-3(\mathrm{~b})(6)$. The statute also lists certain improper purposes, including regulating "matters not related to the purposes of the Act. Id.

112. Id. $\$ 19(\mathrm{~b})(1), 15$ U.S.C. $\S 78 \mathrm{~s}(\mathrm{~b})(1)$.

113. Id. § 19(b)(2)(C)(i), 15 U.S.C. § 78s(b)(2)(C)(i). Conversely, the SEC must disapprove a proposed rule change if it does not make the requisite finding. Id. $\S 19$ (b)(2)(C)(ii), 15 U.S.C. $\S 78 \mathrm{~s}(\mathrm{~b})(2)(\mathrm{C})(\mathrm{ii})$.

114. Id. § 19(c), 15 U.S.C. $\$ 78 \mathrm{~s}(\mathrm{c})$.

115. See infra notes $152-79$ and accompanying text.

116. Order Approving NYSE, NASD, and ASE Proposed Rule Changes relating to the Arbitration Process and the Use of Predispute Arbitration Clauses, 54 Fed. Reg. 21,144 (May 16, 1989) [hereinafter 1989 Approval Order] (describing how the SROs have worked for the past twelve years to develop uniform arbitration rules through the Securities Industry Conference on Arbitration (SICA), which was formed at the SEC's invitation to review arbitration procedures as alternatives to the SEC's own proposals).

117. Brief for the Securities and Exchange Commission as Amicus Curiae Supporting Petitioners, Shearson/Am. Express, Inc. v. McMahon, 482 U.S. 220 (1987) (No. 86-44), 1986 WL 727882.

118. Gross, supra note 24, at 514 (describing how the SEC staff, after McMahon, recommended numerous rule changes to make arbitration fairer and more neutral). For a few years after McMahon, the SEC believed that some brokerage firms did not require customers opening cash accounts to sign PDAAs and thought that competitive forces might cause firms not to require PDAAs. See 1989 Approval Order, supra note 116. By 1996, a well-respected task force studying SRO arbitration reported that "most" individual investors have entered 
FINRA, in turn, actively engages in ongoing reform of its arbitration rules "for the continual improvement of securities industry arbitration as a fair, expeditious, and economical means for the resolution of disputes." ${ }^{\prime 19}$ From 1997 to 2007, for example, FINRA's predecessor, NASD, filed with the SEC more than sixty-five rule proposals on a variety of issues relating to arbitration. ${ }^{120}$ In its review of these proposed rule changes, the SEC consistently expressed its concerns about the fairness of the process. In the view of the SEC, fairness requires that investors have an understanding of the arbitration process and that arbitration should not unduly restrict rights and remedies that investors would have in court. ${ }^{121}$ In short, SEC oversight over SRO securities arbitration has been long-standing and robust. ${ }^{122}$

\section{B. Exchange Act § 29(a)}

Section 29(a) states that "any condition, stipulation, or provision binding any person to waive compliance" with any provision of the Exchange Act or its rules "shall be void." 123 Prior to Dodd-Frank, the statute also applied to rules issued by securities exchanges; Dodd-Frank amended $\S 29$ (a) to include rules issued by all SROs. ${ }^{124}$ Thus, for the first time, $§ 29$ (a) explicitly invalidates provisions in brokerage agreements that require customers to waive compliance with FINRA rules.

Section 29(a) has been part of the Exchange Act since its original enactment. Its legislative history is scant, ${ }^{125}$ but this is not surprising. Congress

into PDAAs. RePORT OF THE ARbitration POLICY TASK ForCE TO THE BoARD OF Governors NAT'L AsSOC. OF SECurities DEAlers, InC. 3 (1996) [hereinafter Ruder REPORT]. By 2007, the Chairman of the Task Force noted that "almost all" individual investors sign PDAAs. See David S. Ruder, Foreword to NASD DisPute Resolution, The ARbitration POLICY TASK FORCE REPORT - A REPORT CARD 1, available at http://www.finra.org/web/groups/industry/@ip/@reg/@guide/documents/industry/p036466.p df.

119. NASD Notice to Members 89-21, Proposed Amendment Re: Predispute Arbitration Clauses in Customer Agreements (Mar. 1989), available at http://finra.complinet.com/en/display/display_main.html?rbid=2403\&element_id=1404.

120. Gross, supra note 24 , at 514 .

121. This history is described more fully in Black \& Gross, supra note 24, at 998-1003.

122. "Agency approval does not appear to be a sure thing." Gross, supra note 24, at 515; see also id. at 512-17 (discussing regulatory filings that reflect a dynamic rule-making process with considerable SEC involvement).

123. 15 U.S.C. $\$ 78 c c$ (2006 \& Supp. V 2011).

124. The same amendment is found in Dodd-Frank Wall Street Reform and Consumer Protection Act $\S \S 927,929 T, 15$ U.S.C. $\$ 78 c c(a)$ (Supp. V 2011) (Equal Treatment of SelfRegulatory Organization Rules).

125. Section 29(a) "was taken verbatim out of the Securities Act," Stock Exchange Practices: Hearings on S. Res. 84, S. Res. 56 and S. Res. 97, Before S. Banking and Currency Comm., 73d Cong. 6578 (1934), reprinted in 6 LEGISLATIVE HistORY OF THE SeCurities ACt OF 1933 AND SeCURities ANd ExChANGe ACT OF 1934 (J. S. Ellenberger \& Ellen Mahar eds., 2001). The legislative history of Section 14 of the Securities Act, 15 
drafted the provision broadly and plainly and must have thought it required no explanation. The Supreme Court long ago identified the statute's central purpose: "§ 29(a) is concerned... with whether the agreement "weakens [customers'] ability to recover under the Exchange Act.",126 The investor protections afforded by the statute and its rules are so important that Congress would not permit parties to negotiate deals that weakened the statutory framework. While the congressional purpose may have been at least partly protective, reflecting a concern that the more sophisticated party might persuade the less sophisticated party to give up his rights, Congress also must have been concerned about the national interest and the importance of federal regulation for the overall fairness and effectiveness of the securities markets. Similarly, there is little discussion about the Dodd-Frank amendment; the need to "provide[] equal treatment for the rules of all SROs under Section 29(a)"127 must have been self-evident.

The Court has considered the interaction between $\S 29$ (a) and arbitration agreements. In McMahon, the Court held that, contrary to a thirty-year-old precedent, ${ }^{128}$ the anti-waiver provision did not render a PDAA unenforceable with respect to federal securities claims. ${ }^{129}$ Although the Court's analysis focused initially on the statutory language and observed that what the statute prohibits are waivers of the statute's "substantive obligations," 130 the Court went beyond this cramped reading. After examining the current state of securities arbitration, the Court concluded that, contrary to the Wilko court's "mistrust of arbitration," "131 the process adequately vindicated the rights of individual customers, principally because of SEC oversight over the SRO arbitration forums. ${ }^{132}$ Thus, the Court expected that the SEC would assure that the process treated investors fairly and adequately protected their rights. The Court did not have occasion, either in McMahon or Rodriguez de Quijas, to consider the implications of $\S 29$ (a) on a PDAA with a class action or consolidated arbitration waiver. ${ }^{133}$

U.S.C. $\S 77 \mathrm{n}$, is silent as to the statute's scope. See Margaret V. Sachs, The Relevance of Tort Law Doctrines to Rule 10b-5: Should Careless Plaintiffs Be Denied Recovery?, 71 CORNELl L. REV. 96, 127 n. 237 (1985).

126. Shearson/Am. Express, Inc. v. McMahon, 482 U.S. 220, 230 (1987) (quoting Wilko v. Swan, 346 U.S. 427 (1953)).

127. S. REP. No. 111-176, at 114 (2010).

128. Wilko, 346 U.S. 427. The Court did not technically overrule Wilko until Rodriguez de Quijas v. Shearson/Am. Exp., Inc., 490 U.S. 477 (1989).

129. 482 U.S. 220 (1987).

130. $I d$. at 228 .

131. Id. at 233 .

132. Id. at 238; Rodriguez, 490 U.S. at 483.

133. McMahon involved a husband and wife with both individual and pension/profitsharing plans; neither the district, appellate nor Supreme Court opinions mention the amount of damages they sought. Rodriguez involved two couples and two individuals who invested a total of $\$ 400,000$. Thus, class treatment was not at issue and the damages claims apparently 
In the 1990s, several circuit courts considered the applicability of $\S 29$ (a) to contracts for underwriting capital between Lloyd's of London and U.S. residents. ${ }^{134}$ According to the plaintiffs, Lloyd's solicited U.S. investors to raise capital and concealed the underwriting risks and massive liabilities relating to asbestos litigation. The contracts specified English choice of law and an English forum for investors' claims, and Lloyd's insisted that execution of the contracts take place on British soil. Although the plain meaning of § 29(a) prohibits a clause mandating application of English law, because such a clause is a "provision binding any person ... to waive compliance with any provision of [the] Act,"135 the circuit courts uniformly upheld the choice of law clause on the ground that these were international transactions among sophisticated investors. Importantly, however, the courts recognized that the available English remedies must be "adequate substitutes" for federal securities laws. ${ }^{136}$ Thus, while these opinions carve out a questionable exception for international securities contracts among sophisticated investors, they do not detract from the McMahon principle that $\S 29$ (a) forbids agreements that weaken investors' protections under federal securities (or equivalent) laws.

Lower courts have interpreted $\S 29$ (a) in the context of contracts other than arbitration agreements. These decisions have established that $\S 29$ (a) does not permit provisions that weaken investors' ability to recover under the federal securities laws, no matter what form they take: "non-reliance" clauses in stock purchase agreements, ${ }^{137}$ "no-action" clauses in indentures, ${ }^{138}$ clauses that provide for an alternative remedy, ${ }^{139}$ or clauses that specify indemnification as the sole remedy. ${ }^{140}$ The only situation in which some courts have enforced nonreliance clauses is negotiated contracts among sophisticated investors or corporate insiders where the written agreement contains specific representations and the non-reliance clause serves the purpose of barring

were large enough to require no aggregation.

134. Bonny v. Soc'y of Lloyd's, 3 F.3d 156 (7th Cir. 1993); Roby v. Corp. of Lloyd's, 996 F.2d 1353 (2d Cir. 1993); Lipcon v. Underwriters at Lloyd's, London, 148 F.3d 1285 (11th Cir. 1998) (recognizing it is a "close question," but following the "weight of circuit authority"); Richards v. Lloyd's of London, 135 F.3d 1289 (9th Cir. 1998) (en banc).

135. See Richards, 135 F.3d at 1297-98 (Thomas, J. dissenting) (quoting $\S 14$ of the Securities Act).

136. Stamm v. Barclays Bank of New York, 153 F.3d 30, 33 (2d Cir. 1998); Richards, 135 F.3d. at 1296.

137. See, e.g., Rogen v. Ilikon Corp., 361 F.2d 260 (1st Cir. 1966); Caiola v. Citibank, N.A., 295 F.3d 312 (2d Cir. 2002) (synthetic trading relationship); AES Corp. v. Dow Chem. Co., 325 F.3d 174 (3d Cir. 2003); MBI Acquisition Partners, L.P. v. Chronicle Publ'g. Co., No. 01-C-177-C, 2001 WL 1478812 (W.D. Wis. Sept. 6, 2001); Roll v. Singh, No. 07-CV04136 (FLW), 2008 U.S. Dist. LEXIS 50125 (D.N.J. June 26, 2008).

138. See, e.g., Kusner v. First Pa. Corp., 531 F.2d 1234 (3d Cir. 1976); McMahan \& Co. v. Wherehouse Entm't, Inc., 65 F.3d 1044 (2d Cir. 1995).

139. See, e.g., Special Transp. Servs., Inc. v. Balto, 325 F. Supp. 1185 (D. Minn. 1971).

140. Citibank, N.A. v. Itochu Int'1, Inc., No. 01 Civ. 6007 (GBD), 2003 WL 1797847 (S.D.N.Y. Apr. 4, 2003). 
representations not contained in the agreement. ${ }^{141}$ While the judiciary's creation of a parol evidence rule exception to $\S 29$ (a) is questionable, it is of limited scope. ${ }^{142}$

While we have not found any case law applying $\$ 29$ (a) to invalidate a provision that waived compliance with an exchange or SRO rule, ${ }^{143}$ under the statute's plain meaning, as recently amended by Dodd-Frank, any contract provision in a brokerage agreement that purports to waive the firm's compliance with any FINRA conduct or arbitration rule is void. Moreover, even if it is appropriate for courts not to apply the statute literally to provisions in contracts among sophisticated parties, this flexibility would not be relevant to a standard-form, adhesion agreement with retail investors.

\section{Exchange Act § $15(\mathrm{o})$}

The third Exchange Act provision authorizing the SEC or FINRA to regulate broker-customer arbitration agreements stems from Dodd-Frank and is a response to the ongoing post-McMahon debate over the fairness of SRO securities arbitration. ${ }^{144}$ The Treasury Department's 2009 white paper on financial reform expressed concern that PDAAs' eliminating access to courts "may unjustifiably undermine investor interests." amendment to the federal securities laws to give the SEC clear authority to prohibit PDAAs in brokerage agreements with retail customers after further study of the issue. ${ }^{146}$ Indeed, Congress has expressed concern over the use of PDAAs in other contexts besides securities arbitration. In 2009, Congress considered, but did not pass, legislation to invalidate PDAAs in employment and consumer arbitration contracts and expressly included securities arbitration

141. Harsco Corp. v. Segui, 91 F.3d 337 (2d Cir. 1996); Rissman v. Rissman, 213 F.3d 381 (7th Cir. 2000) (no discussion of $\S 29$ (a)); see also Harborview Master Fund, L.P. v. Lightpath Tech., Inc., 601 F. Supp. 2d 537 (S.D.N.Y. 2009) (ruling that "big boy" clause in contract between sophisticated parties did not violate $\S 29(\mathrm{a})$ ).

142. See Harsco, 91 F.3d at 343 (recognizing that plaintiff's remedies were weakened, but emphasizing that this was a detailed written agreement negotiated among sophisticated parties). Harsco was distinguished in MBI Acquisition Partners, L.P., 2001 WL 1478812 (distinguishing Harsco because plaintiffs alleged that they attempted to confirm truth of agreement's representations, but were "duped" by false answers).

143. The only reported case directly addressing this issue is Rospigliosi v. Clogher, 46 So. 2d 170 (Fla. 1950), where the court held that a contract between a brokerage firm's employee and his common-law wife to deal in stocks as partners was not invalid as constituting a waiver of the woman's protection under a stock exchange rule that a member's employee may not have an interest in a customer's account. The decision is criticized in 10 LOUis Loss \& JoEl SEligman, SECURITIES REgulation 4581 n.233 (3d ed. 2009).

144. See Gross, supra note 16, at 1182-83, for additional background on the statute.

145. Dep't of the Treasury, Financial Regulatory Reform, A New Foundation: REBUILDING FinANCIAL SUPERVISION AND REgUlation 72 (2009), available at http://www.treasury.gov/initiatives/Documents/FinalReport_web.pdf.

146. $I d$. 
within the definition of "consumer dispute."147

Dodd-Frank contains several provisions that reflect Congress' concern with the use of PDAAs. ${ }^{148}$ Most importantly for this Article, in Dodd-Frank, Congress amended the Exchange Act to give the SEC explicit authority to prohibit, or to impose conditions or limitations on the use of, "agreements that require customers or clients ... to arbitrate any future dispute between them arising under the Federal securities laws, the rules and regulations thereunder, or the rules of a self-regulatory organization if it finds that such prohibition, imposition of conditions, or limitations are in the public interest and for the protection of investors." "Section 15(0) of the Exchange Act is solely enabling and does not require the SEC to take any action. The language imposes a significant limitation on the SEC's authority to prohibit the use of PDAAs: its authority does not extend to future disputes arising under state law. This limitation complicates the SEC's analysis of the appropriate policy because, even if the SEC prohibited PDAAs to the full extent of its authority, firms presumably would still be free to require arbitration of state law claims. This would essentially return the industry to the pre-McMahon bifurcation of federal and state claims, ${ }^{150}$ a result that the SEC could reasonably view as undesirable. ${ }^{151}$

Under $\S 15(0)$, the SEC has the broad authority to ban the use of PDAAs altogether with respect to federal securities class actions and SRO claims, so long as it found that it was in the public interest and for the protection of investors. Ipso facto, the SEC can ban the use of class action waivers, at least

147. See Gross, supra note 16, at 1177-78 (noting that 2009 legislation to invalidate PDAAs expressly extended coverage to securities industry disputes through its definition of "consumer dispute," but also noting that this legislation did not pass).

148. One example is Dodd-Frank $\S 922(\mathrm{c})(2)$, which amended a provision originally adopted by the Sarbanes-Oxley Act of 2002 (SOX), Pub. L. 107-204, 116 Stat. 745 (2002), that created a private right of action for SOX whistleblowers, to prohibit enforcement of PDAAs as well as predispute waivers of retaliation rights and remedies with respect to claims arising under that section. See Dodd-Frank § 922(c)(2), adding 18 U.S.C. § 1514A(e) (Supp. V 2011) (Nonenforceability of Certain Provisions Waiving Rights and Remedies or Requiring Arbitration of Disputes). This provision reflects Congress' judgment that investor protection measures can displace the FAA. See also supra notes 57-61 and accompanying text.

149. 15 U.S.C. $§ 78 o(\mathrm{o})$ (emphasis added). The House Report supporting the bill indicates that Congress added this provision because it was concerned with "securities industry practices [that] have deprived investors of a choice when seeking dispute settlement, too. In particular, pre-dispute mandatory arbitration clauses inserted into contracts have limited the ability of defrauded investors to seek redress." 156 CONG. REC. H5237 (daily ed. June 30, 2010) (statement of Rep. Paul Kanjorski).

150. See Dean Witter Reynolds, Inc. v. Byrd, 470 U.S. 213 (1985) (holding that, when a complaint raises both federal securities law and pendent state law claims, district court must compel arbitration of state law claims and retain jurisdiction over federal statutory claims).

151. See Barbara Black, How to Improve Retail Investor Protection after the DoddFrank Wall Street Reform and Consumer Protection Act, 13 U. PA. J. Bus. L. 59, 103-04 (2010). 
with respect to federal securities and SRO claims, so long as it makes the requisite findings. Congress, recognizing that there were grounds for concern about the use of PDAAs in customer agreements, authorized the SEC to protect investors from brokers' overreaching, even if this conflicts with the policies and purposes of the FAA as interpreted by the Court.

\section{FINRA Rules at Issue in the Schwab Dispute}

We turn now to the pertinent SRO rules and regulations enacted pursuant to these Exchange Act provisions that are involved in the dispute between Schwab and FINRA. In this section, we detail FINRA's reasons for proposing these rules and the SEC's findings in approving the rules.

\section{Disclosures about the arbitration process; prohibiting inconsistent conditions (current FINRA Rule 2268)}

FINRA Rule $2268^{152}$ sets forth requirements for broker-dealers' use of PDAAs for customer accounts. As more fully described below, this rule mandates disclosure of certain information about the arbitration process and prohibits certain conditions that are inconsistent with SRO arbitration. It also sets forth formatting requirements to make the required disclosures more visible and readable. Violation of the rule subjects member firms to disciplinary action $^{153}$ and could lead courts to invalidate any infringing PDAA. ${ }^{154}$

152. FINRA Rule 2268(d) (2011) (originally National Ass'n. of Securities Dealers, Inc., Rules of Fair Practice Art. III, § 21(f) (1989); then renumbered NASD Rule 3110(f) (1996)).

153. See Nat'l Ass'n of Sec. Dealers, Inc., Notice to Members 95-85 (Oct. 1995); Nat'l Ass'n of Sec. Dealers, Inc., Notice to Members 95-16 (Mar. 1995).

154. See supra note 122 and accompanying text. Courts have invalidated securities firms' arbitration clauses that do not comply with agency regulations. See, e.g., Felkner v. Dean Witter Reynolds, Inc., 800 F.2d 1466, 1470 (9th Cir. 1986) (refusing to enforce brokerdealer's arbitration agreement with customer who was engaged in commodities trading because it violated CFTC rules regulating commodities' brokers' arbitration clauses in their customer agreements). Courts also have held that a broker-dealer's violation of an SRO rule voids an arbitration clause in that brokerage firm's customer agreement, if the arbitration agreement specifically incorporated by reference those SRO rules. See Nielsen v. Piper, Jaffray \& Hopwood, Inc., 66 F.3d 145, 148-49 (7th Cir. 1995) (failure to comply with NASD rules regulating arbitration agreement renders pre-dispute arbitration clause invalid); Chor v. Piper, Jaffray \& Hopwood, Inc., 862 P.2d 26, 29 (Mont. 1993) (same); Mueske v. Piper, Jaffray \& Hopwood, Inc., 859 P.2d 444, 450 (Mont. 1993) (same). A few courts have concluded that, if an arbitration clause did not incorporate SRO rules, violation of those rules did not void the arbitration agreement. See J.C. Bradford \& Co. v. Vick, 837 So. 2d 271, 275 (Ala. 2002) (violation of NASD rule does not render PDAA in brokerage agreement void); Cantella \& Co. v. Goodwin, 924 S.W.2d 943 (Tex. 1996) (same). See also Cariveau v. Halferty, 99 Cal. Rptr. 2d 417, 424-25 (Ct. App. 2000) (voiding settlement agreement under 15 U.S.C. $\S 78 \mathrm{cc}(\mathrm{b})$ as a matter of public policy because confidentiality clause violated NASD rules). 
The precursor of FINRA Rule 2268-Article III, Section 21 of the NASD's Rules of Fair Practice - was first adopted in 1989 as part of a package of uniform arbitration rules proposed in response to McMahon by a number of SROs that operated arbitration forums. The rule was designed to improve disclosure to customers in account opening statements and to restrict the content of PDAAs. ${ }^{155}$ Specifically:

The proposals would require broker-dealers that employ predispute arbitration clauses to place immediately before the clause introductory language that would inform customers that they are waiving their right to seek remedies in court, that arbitration is final, that discovery is generally more limited than in court proceedings, that the award is not required to contain factual findings and legal reasoning, and that the arbitration panel typically will include a minority of arbitrators associated with the securities industry.

The proposal requires that the disclosure language be highlighted in four ways. First, large or otherwise distinguishable type must be used. Second, the disclosure language must be set out in outline form so as to be noticeable to readers. Third, a statement, also highlighted, that provides that the agreement contains a predispute arbitration clause, and where that clause is located in the contract, must be inserted into the agreement immediately preceding the signature line. Fourth, a copy of the agreement containing a predispute agreement must be given to the customer, who is to acknowledge receipt of the agreement, either in the agreement itself or in a separate document.

The proposal also prohibits SRO members from having agreements with customers that limit or contradict the rules of any SRO or limit the ability of a party to file any claim in arbitration or limit the ability of the arbitrators to make any award. 156

In approving the rule, the SEC identified two principal benefits to investors. First, the disclosure provisions "address many of the concerns regarding customer notice and choice that have been considered over recent years" and the language "should promote more knowledgeable acquiescence or rejection by customers of arbitration provisions." 157 Second, the prohibition against inconsistent conditions was necessary because "agreements cannot be used to curtail any rights that a party may otherwise have had in a judicial forum." "158 Accordingly, the new rule "appropriately balance[s] the need to strengthen investor confidence in the arbitration systems at the SROs ... with the need to maintain arbitration as a form of dispute resolution that provides for equitable and efficient administration of justice." 159

By 1995, however, NASD became aware that some broker-dealers were using PDAAs containing provisions that were "inconsistent" with the NASD

155. 1989 Approval Order, supra note 116, at 21153.

156. Id.

157. Id . at 21154. At this time, the SEC believed that customers opening cash accounts could find a broker that did not require a PDAA.

158. Id.

159. Id. at 21155 . 
rule or that "subvert[ed] its purposes." 160 Firms were impermissibly attempting to dictate the location for the arbitration hearing, shorten the applicable statute of limitations, and limit the authority of arbitrators to award punitive damages, among other problems. NASD warned that the use of PDAAs that were inconsistent with its Rule 3110(f) may subject NASD members to disciplinary action.

In 1998, NASD found it necessary to file with the SEC a proposed rule change to require additional disclosure in PDAAs about the arbitration process because "investor representatives have expressed concern that many customers who sign predispute arbitration agreements still do not understand adequately what they are agreeing to. Customers' perceptions of unfairness are heightened by the fact that, in order to open an account, they are forced to agree to SROsponsored arbitration." 161 NASD was principally focused on some firms' use of choice-of-law clauses to select a state law that was favorable to the firm ${ }^{162}$ and the perceived unfairness to the customer, who would not understand the significance of the choice of law and its effect on investors' claims.

The rule, as ultimately approved by the SEC in 2004, required a fuller description of differences between arbitration and court proceedings. It retained the prohibition on broker-dealers inserting in their customers' arbitration clauses "any condition that: (1) limits or contradicts the rules of any selfregulatory organization; (2) limits the ability of a party to file any claim in arbitration; ... [and] (4) limits the ability of arbitrators to make any award."163 Instead of mandating language that would regulate choice of law provisions (to which some claimants' representatives objected), the rule added another category of prohibited provision: any that "(3) limits the ability of a party to file any claim in court permitted to be filed in court under the rules of the forums in which a claim may be filed under the agreement." 164 In its approval order, the SEC found that it should provide customers with "clearer and enhanced disclosure regarding the terms of predispute arbitration agreements" and that the new rule "incorporates important protections into the text of the arbitration agreement itself." 165 In addition, the new language prohibiting the use of

160. Nat'l Ass'n of Sec. Dealers, Inc., Notice to Members 95-16 (Mar. 1995).

161. Order Granting Approval to Proposed Rule Change as Amended and Notice of Filing and Order Granting Accelerated Approval to Amendment No. 5 by the National Association of Securities Dealers, Inc., Regarding NASD Rule 3110(f) Governing Predispute Arbitration Agreements with Customers, 69 Fed. Reg. 70293 (Dec. 3, 2004) [hereinafter 1994 Approval Order]. In 2011, the SEC approved FINRA Rule 2268, the successor to NASD Rule 3110(f), without any changes that are relevant to this Article. Order Approving a Proposed Rule Change Adopting FINRA Rules Regarding Books and Records in the Consolidated FINRA Rulebook, 76 Fed. Reg. 5850 (Jan. 27, 2011).

162. E.g., state laws that limited punitive damages; state laws with short statutes of limitations.

163. FINRA R. 2268(d)(1), (2) and (4) (2011).

164. 1994 Approval Order, supra note 161, at 70294.

165. Id. at 70294 . 
restrictive conditions "achieve[d] an appropriate balance between the interests of investors and the ability of parties to agree contractually to fair terms that would govern their disputes." 166 In approving this new language, the SEC reiterated its view that broker-dealer PDAAs could not limit investors' rights and remedies.

\section{Class action claims (current FINRA Rules 12204, 2268(f))}

Prior to 1992, NASD did not have a rule expressly dealing with class claims. Through the public comment process of the 1989 rule changes, one commenter suggested that the SROs should establish procedures for class actions. ${ }^{167}$ The SEC responded that SICA was considering a policy

whereby all SROs will decline jurisdiction over class action litigation unless the class certification and representation issues have first been resolved by a court of competent jurisdiction. At that time, under the SROs' existing rules, both the SROs and the arbitrators for a particular case may determine whether the facilities of the SRO are adequate to handle the litigation, or whether parties should be referred to their remedies at law. ${ }^{168}$

NASD, however, never adopted such a policy. Instead, in 1992, NASD proposed a class action rule in response to the SEC's concern that investors should have access to the courts in appropriate cases, including class actions. ${ }^{169}$ While the rule's language has been rewritten over the years, the substance of the rule has not changed. ${ }^{170}$ First, the NASD arbitration forum would not accept class action claims. ${ }^{171}$ Second, the forum would not permit arbitration of

166. Id. at 70295-96.

167. 1989 Approval Order, supra note 116, at 21154.

168. Id. at n.56.

169. The SEC referred to this as a "suggestion" made by SEC Chairman David Ruder. See Proposed Rule Change by National Association of Securities Dealers, Inc., Relating to Improvements in the NASD Code of Arbitration Procedure, 57 Fed. Reg. 30519, 30520 (July 9, 1992). NASD referred to this as the SEC's “directive." See National Ass'n of Securities Dealers, Inc., Notice To Members 92-65 (Dec. 1992), available at http://finra.complinet.com/en/display/display_main.html?rbid=2403\&element_id=1660.

170. The 2007 revision to reorganize and rewrite the Code provisions in plain English did not make any substantive changes from NASD Rule 10301 to FINRA Customer Code Rule 12204. See Order Approving Proposed Rule Change and Amendments 1, 2, 3, and 4 To Amend NASD Arbitration Rules for Customer Disputes and Notice of Filing and Order Granting Accelerated Approval of Amendments 5, 6, and 7 Thereto; Order Approving Proposed Rule Change and Amendments 1, 2, 3, and 4 To Amend NASD Arbitration Rules for Industry Disputes and Notice of Filing and Order Granting Accelerated Approval of Amendments 5, 6, and 7 Thereto, 72 Fed. Reg. 4574-01, 4580 (Jan. 31, 2007) [hereinafter 2007 Approval Order].

171. The SEC recently approved another FINRA proposed rule change to clarify that collective actions brought under the Fair Labor Standards Act cannot be arbitrated in the FINRA forum, in response to a judicial decision interpreting FINRA Customer Code Rule 12204 to the contrary. See Notice of Filing of Amendment No. 1 and Order Granting Accelerated Approval of a Proposed Rule Change, as Modified by Amendment No. 1, 
individual claims based on the same facts and law and involving the same defendants as in a class-certified or putative class action unless the claimant established that he was not participating in the class action. Third, the broker may not enforce any arbitration agreement against a member of a certified or putative class action until the class action was denied certification or the member was excluded or withdrew from the class. ${ }^{172}$ Finally, FINRA amended the rule governing the content of PDAAs to require a statement prohibiting persons from bringing class actions in arbitration and from attempting to enforce an arbitration agreement against a member of a class action. ${ }^{173}$

In proposing the bar on class actions in the arbitration forum, NASD made clear its view that investors should have the opportunity to pursue class claims in appropriate cases. It determined that courts were the preferable forum for class claims, because they already had in place procedures to manage class claims. Moreover, firms should not be able to defeat class actions by enforcing an arbitration agreement against class members. Thus, the NASD rule recognized that class actions were important for investor protection and reflected an efficient allocation of resources between two dispute resolution systems. Accordingly, the proposed rule provided that class actions and claims of individual class members would not be eligible for arbitration at NASD, regardless of any PDAA. ${ }^{174}$

In approving the rule, the SEC expressed its agreement with NASD's position that investors should have access to courts to pursue class action claims:

in all cases, class actions are better handled by the courts and that investors should have access to courts to resolve class actions efficiently. In the past, individuals who attempted to certify class actions in litigation were subject to enforcement of their separate arbitration contracts by their broker-dealers. Without access to class actions in [appropriate] cases, both investors and broker-dealers have been put to the expense of wasteful, duplicative litigation....

... The Commission believes that investor access to the courts should be preserved for class actions. . . ${ }^{175}$

Amending Rule 13024 of the Code of Arbitration Procedure for Industry Disputes To Preclude Collective Action Claims From Being Arbitrated, 77 Fed. Reg. 22374 (Apr. 9, 2012). This approval order reiterated two principles: collective actions belong in courts, and access to courts for class or collective action litigation should be preserved.

172. FINRA CUSTOMER CODE R. 12204 (2008) (originally NASD Rules of Fair Practice Art. III $\S 12$ (d) (1992), then renumbered NASD Rule 10301 (1996)).

173. FINRA R. 2268(f) (2011) (originally NASD Rules of Fair Practice Art. III, § 21(f) (1992), then NASD Rule 3110(f) (1996)).

174. Order Approving Proposed Rule Change Relating to the Exclusion of Class Actions from Arbitration Proceedings, 57 Fed. Reg. 52659, 52660 (Nov. 4, 1992).

175. Id. at 52661 . 
3. Joinder of claims (current FINRA Rules 12312, 12313, 12314)

Investors may benefit by combining similar claims to achieve efficiencies and cost-savings. FINRA permits joinder of claims in certain circumstances. ${ }^{176}$ Claimants may join multiple claims in the same arbitration if (1) the claims contain common questions of law or fact, and (2) the claims assert any right to relief jointly and severally, or the claims arise out of the same transaction or occurrence, or series of transactions or occurrences. The Director of Arbitration has the discretion to consolidate or sever claims; his discretion is preliminary and may be reconsidered by the panel. ${ }^{177}$ NASD's pre-McMahon arbitration rules contained a provision permitting joinder of similar claims; ${ }^{178}$ the substance of the provisions has not changed during the subsequent revisions of the arbitration rules and has engendered little discussion. ${ }^{179}$

In the next Part, we narrow in on the conflict between Schwab and FINRA with respect to the class and consolidated action waiver in the Schwab customer agreement.

\section{THE SCHWAB-FINRA SHOWDOWN}

In October 2011, FINRA member Schwab amended its customer agreement to force customers to agree not to bring or participate in class actions or class arbitrations against Schwab. ${ }^{180}$ In addition, the amended agreement requires customers to agree that arbitrators have no authority to consolidate more than one party's claims. Instead, customers must bring their claims "solely in individual capacities.", 181

In response, in early 2012, FINRA Enforcement filed a disciplinary action against Schwab, challenging Schwab's actions as a violation of several provisions of FINRA's rules. ${ }^{182}$ Specifically, Schwab's new PDAA language

176. FINRA CUSTOMER CODE R. 12312 (2008), 12313 (2008), 12314 (2011).

177. FINRA CUSTOMER CODE R. 12312 (2008).

178. Nat'l Ass'n of Sec. Dealers, Inc., Code of Arbitration Procedure, § 25(c). The NASD Code in effect in July 1987 is republished as Exhibit 24 of SECURITIES ARbitration 1988, at 399 (PLI Corp. Law \& Practice Course, Handbook Series No. 601, 1988). Clarifying changes to the language were made in 1991. Order Granting Approval to Proposed Rule Change Relating to Improvements in the NASD Code of Arbitration Procedure, 56 Fed. Reg. 22029-02 (May 13, 1991).

179. The predecessor of the current rules was NASD Rule 10314(d). The 2007 revision of the Code did not change its substance. 2007 Approval Order, supra note 170.

180. Complaint For Declaratory and Preliminary and Permanent Injunctive Relief $\mathbf{J} 26$, Charles Schwab \& Co. v. Fin. Indus. Regulatory Auth., Inc., 861 F. Supp. 2d 1063 (N.D. Cal. 2012) (No. CV 12-0518) (alleging that Schwab inserted a new clause entitled "Waiver of Class Action or Representative Action" in its Customer Account Agreements).

181. Id.

182. Complaint and Request for Expedited Hearing, Dept. of Enforcement v. Charles Schwab \& Co., FINRA Disciplinary Proceeding No. 2011029760201 (Feb. 1, 2012), available at http://disciplinaryactions.finra.org/viewdocument.aspx?DocNB=29288. 
violates FINRA Rule $2268(\mathrm{~d})(1)^{183}$ and $2268(\mathrm{~d})(3)^{184}$ (and its predecessor rule), which in turn is a violation of FINRA Rule 2010, requiring a member, "in the conduct of its business, [to] observe high standards of commercial honor and just and equitable principles of trade." ${ }^{185}$ FINRA argues that, because Rule 12204(d) of the FINRA Code of Arbitration Procedure for Customer Disputes addresses the manner in which customers can bring and participate in class actions against member firms, ${ }^{186}$ the forum rules clearly permit class actions in court, and Schwab's class action waiver contradicts Rule $12204 .{ }^{187}$ In addition, although the Schwab agreement contains the disclosures mandated by Rule 2268 , the class action waiver and prohibition on joinder flatly contradict the required disclosures. ${ }^{188}$ FINRA seeks an order that Schwab cease from further violating Rule 2268 as well as sanctions.

To attempt to moot the FINRA enforcement action, Schwab simultaneously filed an action in the U.S. District Court for the Northern District of California ${ }^{189}$ seeking a declaratory judgment that FINRA "may not enforce its rules regulating broker-dealers in a manner inconsistent with the Federal Arbitration Act as most recently interpreted by [the Court's decisions in AT\&T Mobility and CompuCredit]. ${ }^{190}$ In its complaint, Schwab argued that the FAA bars FINRA from proceeding with its disciplinary action and "the FAA requires enforcement of class action waivers absent a Congressional command to the contrary."191 Although Schwab acknowledged that FINRA's rules have the "force of federal law" as they are derived from the Exchange Act, ${ }^{192}$ Schwab neither acknowledged nor addressed the argument that the FAA yields to the Exchange Act.

On February 21, 2012, Schwab filed a motion for preliminary injunction in its declaratory judgment action, reasserting its arguments. On February 22, FINRA in turn filed a motion to dismiss for lack of subject matter jurisdiction.

183. See supra notes 152,163 and accompanying text.

184. See supra note 164 and accompanying text.

185. FINRA R. 2010 (Standards of Commercial Honor and Principles of Trade), available at http://finra.complinet.com/en/display/display.html?rbid=2403\&record_id=6905 \&element_id=5504\&highlight=2010\#r6905.

186. Likewise, Rule 13204 of the Code of Arbitration Procedure for Industry Disputes precludes arbitration of intra-industry class action disputes. See Gomez v. Brill Secs., Inc., 943 N.Y.S.2d 400 (App. Div. 2012) (refusing to compel arbitration of, inter alia, labor law claims by brokerage firm employees that were subject of putative class action).

187. FINRA Complaint, supra note 182, at 9 I 17-20.

188. Id. IJ 23-26; 29-32.

189. Complaint For Declaratory and Preliminary and Permanent Injunctive Relief, Charles Schwab \& Co. v. Fin. Indus. Regulatory Auth., Inc., 861 F. Supp. 2d 1063 (N.D. Cal. 2012) (No. CV 12-0518). Schwab offered to pay its customers' arbitration filing fees pending the outcome of its suit.

190. Id. at 2 .

191. Id. at 32 .

192. Id. at IJ3. 
Noting that Schwab instituted this judicial proceeding within hours after the disciplinary complaint was served, FINRA argued that Schwab failed to meet the prerequisite for filing a federal lawsuit-exhaustion of its administrative remedies. 193

On May 11, 2012, the federal district court in California granted FINRA's motion to dismiss Schwab's complaint on the ground that Schwab failed to exhaust its administrative remedies and thus the court lacked jurisdiction to hear the complaint. ${ }^{194}$ Notably, the court stated that the interpretation of FINRA's Rule 2268, which FINRA argued prohibits brokerage firms from including a class action waiver in their arbitration clauses, is an issue "squarely within the expertise of FINRA, as well as the SEC." Schwab announced soon after the district court's decision that it would not enforce the class action waiver in its customer agreements until the FINRA disciplinary action is final, and the time to appeal from that decision has lapsed. ${ }^{195}$

Schwab's brazen challenge to FINRA's authority to proscribe language in its customer arbitration clauses raises, on its merits, an issue no court appears to have addressed: does the FAA's mandate to treat arbitration agreements the same as other contracts and to enforce them according to their terms yield in the face of the conflicting policy of the Exchange Act to assure fairness and to protect investors?

\section{RECONCILING THE CONFLICT BETWEen the FAA AND THE EXCHANGE ACT}

As described above, the Schwab controversy poses a direct conflict between the policies of the FAA and the Exchange Act. ${ }^{196}$ Which statute governs? On the one hand, in Casarotto, the Court held that the FAA displaces a state law that imposes specific disclosure requirements on arbitration agreements. ${ }^{197}$ In AT\&T Mobility, the Court upheld a class action waiver because states cannot restrict the terms in an arbitration agreement even if "desirable for unrelated reasons." 198 On the other hand, the Court has declared repeatedly that the FAA's mandate is not absolute: it "may be overridden by a contrary Congressional command." 199

193. Id. Schwab did not assert valid reasons for bypassing the disciplinary proceeding - either that the disciplinary proceeding would be too time-consuming or that the FINRA and SEC adjudicators lack the expertise to address issues outside of securities law or FINRA rules.

194. See Charles Schwab \& Co., 861 F. Supp. 2d 1063.

195. Schwab To Hold Off Enforcing Class Action Waivers, Westlaw J. Class Action, June 21,2012 , at 1 (reporting that Schwab spokesperson announced the company "'does not have plans to enforce the waiver until the FINRA matter is resolved"').

196. See supra notes 178-93 and accompanying text.

197. Doctor's Assocs., Inc. v. Cararotto, 517 U.S. 681, 687 (1996).

198. AT\&T Mobility v. Concepcion, 131 S. Ct. 1740, 1753 (2011).

199. Shearson/Am. Exp., Inc. v. McMahon, 482 U.S. 220, 226-27 (1987); CompuCredit 
The Exchange Act gives the SEC and FINRA broad authority to regulate the broker-dealer industry in order to protect investors. FINRA regulations promulgated pursuant to the Exchange Act-which have the force of federal law-impose specific disclosure requirements on arbitration agreements, forbid class action waivers and permit joinder of claims, in order to make the arbitration process fairer. As described more fully below, under accepted canons of statutory construction, including the implied repeal doctrine, as well as under Exchange Act and FAA jurisprudence, FINRA's regulations of arbitration clauses in brokerage firms' customer agreements should prevail in the face of a challenge under the FAA because, consistent with the policies underlying the Exchange Act, they were adopted to assure fair treatment and protect investors.

\section{A. The FAA is Impliedly Repealed by the Exchange Act}

\section{The traditional doctrine of implied repeal}

When inconsistent laws emanate from a single legislature, absent an express exemption clause in either, the Supreme Court reconciles them by applying the long-standing canon of statutory construction known as the implied repeal doctrine. Long disfavored and limited to narrow circumstances, ${ }^{200}$ the doctrine applies only when necessary to make a later enactment work, ${ }^{201}$ and even then applies only to the extent necessary to reconcile the conflicting laws. ${ }^{202}$ The burden is on the party seeking the implied repeal to show congressional intent to override the former law, which can be proven through (1) the text of the law, (2) its legislative history, or (3) an inherent conflict between the edict of the former law and the underlying purpose of the latter. ${ }^{203}$ "Although not explicitly stated in the case law, it is self-evident that the 'inherent conflict' test requires a balancing of the

Corp. v. Greenwood, 132 S. Ct. 665, 669 (2012).

200. See, e.g., United States v. Borden Co., 308 U.S. 188, 198 (1939); United States v. Nat'l Ass'n of Sec. Dealers, 422 U.S. 694, 734 (1975) (implied repeal limited to "particular and discrete instances" where an appeal was "necessary to make the [regulatory scheme] work") (alteration in original) (quoting Silver v. N.Y. Stock Exch., 373 U.S. 341, 357 (1963)).

201. "Where there are two acts upon the same subject, effect should be given to both if possible." Posadas v. Nat'l City Bank of N.Y., 296 U.S. 497, 503 (1936).

202. See Silver, 373 U.S. at 357; Branch v. Smith, 538 U.S. 254, 273 (2003); For a detailed discussion of the traditional doctrine, see Jesse W. Markham, Jr., The Supreme Court's New Implied Repeal Doctrine: Expanding Judicial Power To Rewrite Legislation Under the Ballooning Conception of "Plain Repugnancy," 45 GoNZ. L. REV. 437, 454-55 (2009) (citations omitted); Karen Petroski, Retheorizing the Presumption Against Implied Repeals, 92 CALIF. L. REV. 487 (2004).

203. McMahon, 482 U.S. at 226-27. 
legislative interests in play in a particular case."204

Under the traditional test for implied repeal, if the latter law is "plainly repugnant" to the former so that they cannot be read as a single law, then the latter enactment "impliedly repeals" the former. ${ }^{205}$ However, "[i]mplied repeal does not automatically result from the mere existence of a newer statute on the same subject; such a construction of the doctrine would mean the legislature could never enact complementary, remedial, or cumulative laws in the same area." 206

Professor Markham eloquently described the doctrine:

One of the oldest canons of statutory interpretation is the implied repeal doctrine, whose earliest articulation is found in Lord Coke's 1614 decision in Dr. Foster's Case. In its traditional formulation, implied repeal has been understood to be a very narrow doctrine that reconciles older and newer enactments by minimally paring back older law where there is no plausible understanding of the laws that can avoid the inconsistency. Courts apply this doctrine rarely because it is limited to reconciling laws that are so 'plainly repugnant' to one another that they are incapable of coexisting. Even when faced with plainly incompatible enactments, the doctrine allows for only the most modest displacement of the earlier law. 207

The Supreme Court has applied the traditional test to displace federal antitrust laws in favor of conflicting securities laws. In Gordon v. New York Stock Exchange ${ }^{208}$ a group of investors challenged as anticompetitive the New York Stock Exchange's and American Stock Exchange's rules that fixed commission rates. ${ }^{209}$ In light of text in the Exchange Act $^{210}$ specifically authorizing the SEC to fix reasonable rates of commission along with legislative history of recent amendments, ${ }^{211}$ the Court found that an implied repeal of the Sherman Act was necessary to fulfill the intent of Congress. ${ }^{212}$ Likewise, in United States v. National Association of Securities Dealers, ${ }^{213}$ the United States challenged SEC regulations, NASD rules and agreements among

204. AmeriCorp, Inc. v. Hamm, 2:11-CV-677-MEF, 2012 WL 1392927, at *3 (M.D. Ala. Apr. 23, 2012)

205. Posadas, 296 U.S. at 503-04.

206. Markham, Jr., supra note 202, at 455.

207. Id. at 439 (citations omitted).

208. 422 U.S. 659 (1975)

209. Id. at 660-61.

210. Exchange Act § 19(b)(9), 15 U.S.C. § 78s (2006 \& Supp. V 2011).

211. Gordon, 422 U.S. at 665-67. In a confusing factual twist, the relevant amendments, which did not take effect until after the case was heard before the Supreme Court, banned the very practice challenged as anticompetitive. Id. at 690 . While this indicates Congress' intent was in fact compatible with the plaintiffs' interpretation of antitrust laws on the subject matter of commission rate fixing, the Court focused on the continued grant of regulatory and oversight power to the SEC, which would allow the SEC to set fixed commission rates in the future. Id. at 665-67.

212. Id. at 691 .

213. 422 U.S. 694 (1975) 
mutual fund companies that restricted the transferability of mutual fund shares on the secondary market for a price other than the initial public offering. ${ }^{214}$ The relevant portions of the Investment Company Act permitted funds to make their own transferability restrictions so long as the SEC did not affirmatively disapprove of the provision. ${ }^{215}$ Again finding that the SEC was actively engaged in oversight-even if not acting in the specific instances in questionthe Court held that the Sherman Act was impliedly repealed by the subsequent grant of authority to the SEC. ${ }^{216}$

\section{The Credit Suisse formulation of implied repeal}

The Court employed the "plain repugnancy" test for over a century, only very recently loosening its stringency. ${ }^{217}$ Thus, in Credit Suisse Securities (USA) LLC v. Billing, ${ }^{218}$ the Court refined the "plain repugnancy" test by adding four factors for courts to consider when choosing between conflicting federal laws. Credit Suisse stemmed from a class action against multiple investment banks, which formed underwriting syndicates for the initial public offerings (IPO) of technology companies. Plaintiffs alleged violations of the federal antitrust laws through the underwriters' various IPO sales practices, including laddering and tying, that artificially inflated stock prices and resulted in excessive commissions to investors. ${ }^{219}$ The underwriters moved to dismiss the antitrust complaints "on the ground that federal securities laws [including SEC regulations and NASD Conduct Rules] impliedly precludes application of antitrust laws to the conduct in question."220 After the district court dismissed the complaints and the Second Circuit Court of Appeals reversed, the Supreme Court granted certiorari.

The Court first looked to its precedent that specifically addressed conflicts between securities law and antitrust law. ${ }^{221}$ After surveying that authority, the Court articulated four factors relevant to determining whether "there is a "clear repugnancy' between the securities law and the antitrust complaint-or as we shall subsequently describe the matter, whether the two are "cclearly incompatible"':

(1) The existence of regulatory authority under the securities law to supervise the activities in question; (2) evidence that the responsible regulatory entities exercise that authority;... (3) a resulting risk that the securities and antitrust

214. Id. at $700-02$.

215. Id. at 726 .

216. Id. at 734-35.

217. Markham, Jr., supra note 202, at 439 (stating that the traditional "narrow formulation of implied repeal has had a long and steady history - until now").

218. 551 U.S. 264 (2007)

219. Id. at 267-70.

220. $I d$. at 270 .

221. Id. at 271-75. 
laws, if both applicable, would produce conflicting guidance, requirements, duties, privileges, or standards of conduct [and] (4) the possible conflict affect[s] practices that lie squarely within an area of financial market activity that the securities law seeks to regulate. ${ }^{222}$

Applying this four-factor test, the Court readily concluded that the SEC was authorized to and in fact had on several occasions regulated the underwriting process, a process important to financial market activities regulated by securities laws. ${ }^{223}$ The Court also decided that the complexity of the SEC regulations and the fact that the same evidence would be used to prove causes of action under both laws made it possible that courts could generate conflicting opinions in mixed antitrust-securities suits about acceptable underwriting practices, thus creating a conflict. ${ }^{224}$ The Court thus found clear incompatibility between these potential inconsistencies, even though the specific practices at issue had been clearly condemned by the SEC. ${ }^{225}$

\section{Precedent for implied repeal of the FAA}

The Court once considered an alleged conflict between the FAA and the Exchange Act under the traditional test for implied repeal. In McMahon, investors argued that Exchange Act $\S 29$ (a) (the anti-waiver provision) barred the arbitrability of claims arising under the Act, but the broker-dealer argued that the FAA mandated enforcement of the arbitration agreement for the statutory claims. The Court analyzed the conflict as an "implied repeal" question and announced that "the burden is on the party opposing arbitration ... to show that Congress intended to preclude a waiver of judicial remedies for the statutory rights at issue," and that such intent would be "“deducible from [the statute's] text or legislative history,' or from an inherent conflict between arbitration and the statute's underlying purpose."226 Ultimately, the Court found that Congress did not intend to require a judicial forum for the resolution of individual Exchange Act claims, and that arbitration conducted pursuant to procedures approved by the Commission does not weaken investors' ability to recover under the Act. ${ }^{227}$ Because the McMahons'

222. Id. at $275-76$.

223. Id. at 276-77.

224. Id. at 279-80.

225. Id. at 279. Since Credit Suisse, several lower federal courts have found that the federal securities laws impliedly repeal the antitrust laws in other contexts. See, e.g., Elec. Trading Grp., LLC v. Banc of Am. Sec. LLC, 588 F.3d 128, 134-38 (2d Cir. 2009) (prime brokerage business with short sellers); Mayor of Baltimore v. Citigroup, Inc., Nos. $08 \mathrm{Cv}$. 7746 (BSJ), 08 Cv. 7747 (BSJ), 2010 WL 430771 (S.D.N.Y. Jan. 26, 2010) (investigation and regulation of auction-rate securities).

226. Shearson/Am. Exp., Inc. v. McMahon, 482 U.S. 220, 226-27 (1987) (citing Mitsubishi Motors Corp. v. Soler Chrysler-Plymouth, Inc., 473 U.S. 614, 628, 632-37 (1985)).

227. Id. at 227-38. 
arbitration agreement with Shearson did not interfere with their rights protected by the Exchange Act, the Exchange Act did not conflict with the FAA, and both statutes could coexist.

In contrast, lower federal courts have found implied repeal of the FAA in the face of other conflicting federal statutes. For example, several circuits have declined to enforce an otherwise valid arbitration agreement in core bankruptcy proceedings because it would conflict with the underlying purposes of the federal Bankruptcy Code. ${ }^{228}$ Similarly, the Ninth Circuit found that the Carmack Amendment, which was originally enacted before the FAA in 1906, and which regulates contract claims for interstate shipping and disallows arbitration agreements, displaced the FAA. ${ }^{229}$ Because the relevant portions of the statute creating a conflict had been added by amendment after enactment of the FAA, the court found that the FAA was impliedly repealed. ${ }^{230}$

In addition, administrative agencies have ruled that the FAA yields to their interpretation that claims arising under statutes they are mandated to enforce are not arbitrable. For example, the Federal Trade Commission has concluded that claims arising under the Magnuson-Moss Warranty Act are not arbitrable. $^{231}$ The National Labor Relations Board recently held that federal labor law, which emphasizes the right of employees to join in collective action and provides a substantive right to engage in "concerted activity," bars collective and class action waivers in labor and employment contracts, even in an arbitration agreement. ${ }^{232}$

The foregoing authorities demonstrate that it would not be unprecedented for a federal court or the SEC, upon review of a FINRA disciplinary action, to reason that the FAA is impliedly repealed by the Exchange Act for purposes of invalidating a class action waiver in a broker-dealer's PDAA. In the next section, we establish that the Supreme Court's current test for implied repeal

228. See In re Nat'l Gypsum, 118 F.3d 1056, 1067-68 (5th Cir. 1997); In re U.S. Lines, 197 F.3d 631, 640 (2d Cir. 1999); In re White Mountain Mining Co., 403 F.3d 164, 169 (4th Cir. 2005); In re Thorpe Insulation Co., 671 F.3d 1011 (9th Cir. 2012).

229. Smallwood v. Allied Van Lines, Inc., 660 F.3d 1115, 1120-21 (9th Cir. 2011) (tort and contract claims against a shipping company not arbitrable).

230. Id. at 1124-25.

231. Final Action Concerning Review of Interpretations of Magnuson-Moss Warranty Act, 64 Fed. Reg. 19700-01 (Apr. 22, 1999) (reaffirming Rule 703 it promulgated in 1975 interpreting MMWA to preclude PDAAs in warranty agreements). But see Kolev v. Euromotors/The Auto Gallery, 676 F.3d 867 (9th Cir. 2012) (withdrawing earlier opinion that held that buyer's Magnuson-Moss Warranty Act claims were not subject to arbitration).

232. See D.R. Horton, Inc., 357 N.L.R.B. No. 184 at 9 (2012) (citing National Labor Relations Act $\S 7$, which provides employees' right to engage in "concerted activities" for "mutual aid or protection"). The NLRB based its holding on both an implied repeal analysis and a public policy defense to contract enforcement as permitted by the FAA's savings clause. The company's appeal is pending in the Fifth Circuit, and federal district courts are divided on the issue. See, e.g., Delock v. Securitas Sec. Servs. USA, Inc., 2012 WL 3150391 (E.D. Ark. Aug. 1, 2012) (rejecting NLRB's position because of CompuCredit and certifying issue for interlocutory appeal). 
requires the invalidation of Schwab's class action waiver.

\section{The Exchange Act and FINRA Rules displace the FAA}

Under the "plain repugnancy" standard as refined by the four Credit Suisse factors, FINRA rules governing the arbitration process and a brokerdealer/customer PDAA, promulgated with SEC approval, impliedly repeal the FAA to the extent they are in conflict. First, as discussed supra, ${ }^{233}$ three provisions of the Exchange Act empower the SEC (either directly or through its oversight of FINRA) to regulate the arbitration process and PDAAs in customer agreements: $\S 15 \mathrm{~A}, \S 29(\mathrm{a})$, and, most recently and pertinently, $\S$ $15(\mathrm{o})$. In $\S 15(\mathrm{o})$, Congress gave the SEC the express power to prohibit, or to impose conditions or limitations on a broker-dealer's use of a customer PDAA "if it finds that such prohibition, imposition of conditions, or limitations are in the public interest and for the protection of investors."234 Thus, the SEC has the express authority to ban PDAAs altogether in customer agreements, as well as the power to impose any condition or limitation on that PDAA, which surely includes an anti-investor provision such as a class action waiver. ${ }^{235}$

Second, the SEC has regularly and consistently exercised this authority at least since McMahon ${ }^{236}$ through its general oversight of the FINRA arbitration forum $^{237}$ and, specifically, through its review and approval of FINRA Conduct Rules as well as FINRA's multiple Codes of Arbitration Procedure. Recent rule changes in the arbitration area approved by the SEC are further evidence of this active regulation. ${ }^{238}$

233. See supra Parts II.A-II.C.

234. Exchange Act, $\S 15(0), 15$ U.S.C. $\S 78 o(0)$; see also supra note 149 and accompanying text.

235. This recent and clear expression of congressional intent to authorize the SEC to regulate customers' PDAAs differentiates the Exchange Act from other statutes that courts have declined to view as a "contrary congressional command" overriding the FAA. See, e.g., CompuCredit Corp. v. Greenwood, 132 S. Ct. 665, 673 (2012) (Credit Repair Organizations Act); Johnson v. West Suburban Bank, 225 F.3d 366, 374-75 (3d Cir. 2000) (Truth in Lending Act).

236. See FINRA R. 2268; see also Shearson/Am. Exp., Inc. v. McMahon, 482 U.S. 220 , 226-27 (1987) ("In the exercise of its regulatory authority, the SEC has specifically approved the arbitration procedures of . . . the NASD.").

237. Dodd-Frank $\S 964$ requires the Government Accountability Office (GAO) to review SEC oversight of FINRA and specifically refers to arbitration services. The GAO issued its first report in May 2012, see generally U.S. Gov'T ACCOUNTABILITY OFFICE, GAO 12-625, SECurities Regulation: OpPortunities EXIst to Improve SEC's Oversight of THE FINANCIAL INDUSTRY REGULATORY AUTHORITY (discussing SEC oversight of arbitration program and noting that inspections have not been conducted as frequently as planned).

238. See, e.g., Order Approving a Proposed Rule Change Raising the Limit for Simplified Arbitration from $\$ 25,000$ to $\$ 50,000,77$ Fed. Reg. 27262 (May 9, 2012); Notice of Filing of Amendment No. 1 and Order Granting Accelerated Approval of a Proposed Rule Change to Amend the Code of Arbitration Procedure for Industry Disputes to Preclude Collective Action Claims From Being Arbitrated, 77 Fed. Reg. 22374 (Apr. 13, 2012) 
Third, conflict between FINRA rules and the FAA is not only possible, it has happened in the context of the Schwab dispute. First, the FAA mandates enforcement of arbitration agreements according to their terms, whereas FINRA Rule 2268- which requires member firms to preserve the class action remedy for investors ${ }^{239}$ - precludes Schwab from enforcing its arbitration agreement with its customers as written. ${ }^{240}$ Additionally, FINRA Rule 12204 prescribes the manner in which customers can bring and participate in class actions against member firms, and Rules 12312-14 empower arbitrators to consolidate claims. ${ }^{241}$ Therefore, FINRA forum rules, which clearly permit class actions in court and joinder of claims in arbitration to further the statute's underlying purpose of investor protection, conflict with Schwab's class and consolidated action waiver. This conflict also satisfies McMahon's requirement that the opponent of arbitration demonstrate "an inherent conflict between arbitration and the [Exchange Act's] underlying purpose."242

It is possible, and perhaps preferable, to find no conflict between the FAA and the FINRA rules at issue. Unlike the Montana statute held invalid in Cassarotto, which required a warning about arbitration and thus reflects antiarbitration bias, the FINRA rules at issue are intended to make investors aware of the "existence, nature, and effect of PDAAs"243 and to improve SRO arbitration so that it is a "fair, expeditious, and economical means for resolution

[hereinafter Collective Action Approval Order]; see also Gross, supra note 24, at 514-17 (describing SEC's robust oversight of frequent FINRA Dispute Resolution rule changes).

239. In approving Rule 2268, the SEC explicitly declared that it intended the rule to preserve the class action in court as a remedy for investors. See supra note 173 and accompanying text.

240. Because Rule 2268, by its terms, applies only to firms' agreements with their customers, courts have upheld class action waivers in broker-dealers' agreements with their employees. See Suschil v. Ameriprise Fin. Servs., Inc., No. 1:07CV2655, 2008 WL 974045, at *5-6 (N.D. Ohio Apr. 7, 2008); Lewis v. UBS Fin. Servs., Inc., 818 F. Supp. 2d 1161, 1168 (N.D. Cal. 2011); Dauod v. Ameriprise Fin. Servs., Inc., No. 8:10-cv-00302CJC(MANx), 2011 WL 6961586, at *5 (C.D. Cal. Oct. 12, 2011); Cohen v. UBS Fin. Serv., Inc., 12 Civ. 2147 (BSJ) (JLC), 2012 WL 6041634 (S.D.N.Y. Dec. 4, 2012). At least two courts rejected the argument that Rule 13204 of the Code of Arbitration Procedure for Industry Disputes barred a class action waiver in a member firm's employment agreement. See Suschil, 2008 WL 974045, at *6 (reasoning that the phrase "[t]his paragraph does not otherwise affect the enforceability of any rights under the Code or any other agreement" precluded any argument that Rule 13204 barred broker-dealers from separately agreeing with their customers to waive their class action rights); Cohen, 2012 WL 6041634, at *3. FINRA, however, recently reaffirmed its position that "access to courts for class or collective action litigation should be preserved for associated persons." Notice of Filing of Proposed Rule Change to Amend the Code of Arbitration Procedure for Industry Disputes to Preclude Collective Action Claims From Being Arbitrated, 77 Fed. Reg. 1773, 1774 (Jan. 11, 2012).

241. See supra notes 171-74, 176-77 and accompanying text.

242. Shearson/Am. Exp., Inc. v. McMahon, 482 U.S. 220, 226-27 (citing Mitsubishi Motors Corp. v. Soler Chrysler-Plymouth, Inc., 473 U.S. 614, 628, 632-37 (1985)).

243. Proposed Rule Change Relating to Predispute Arbitration Clauses in Customer Agreements, 54 Fed. Reg. 15,860 (Apr. 12, 1989). 
of disputes," 244 taking into account the interests of investors, broker-dealers and the public. These SEC-approved FINRA rules reflect concern for arbitration's fairness rather than anti-arbitration bias. Indeed, the SEC expressed its support for SRO arbitration at the time of McMahon. ${ }^{245}$ In contrast, the FAA's underlying purpose is to eliminate laws that demonstrate an anti-arbitration bias. ${ }^{246}$ Under this interpretation, the FINRA rules still prevail. A court could apply FINRA rules as written because they do not "stand as an obstacle to the accomplishment of the FAA's objectives." 247

As for the fourth Credit Suisse factor-the type of conduct sought to be regulated-resolution of disputes and investor protection is at the core of the relationship between customers and broker-dealers, which the Exchange Act clearly intended to regulate. ${ }^{248}$ Congress understood that investor confidence was essential for the maintenance of effective securities markets and that market forces alone could not ensure adequate investor protection. ${ }^{249}$ This is particularly the case with respect to the broker-dealer industry since it performs activities that are essential to the securities markets. ${ }^{250}$ Moreover, the confidence of retail investors in securities markets is highly dependent on their trust and confidence in the broker-dealers and their associated members with

244. E.g., NASD Notice to Members 89-21, supra note 119. The Ruder Report, for example, found that arbitration is preferable to civil litigation and recommends additional uniform "investor-friendly" provisions because PDAAs are generally not the result of arm's length negotiations. RUDER REPORT, supra note 118, at 7-8.

245. See Brief for the Securities and Exchange Commission as Amicus Curiae Supporting Petitioners, Shearson/Am. Express, Inc. v. McMahon, 482 U.S. 220 (1987) (No. 86-44), 1986 WL 727882, at *13 (arguing that 1975 enhancements to Commission's authority to regulate SRO arbitration renders it "adequate to enforce substantive duties under the securities laws").

246. AT\&T Mobility, LLC v. Concepcion, 131 S. Ct. 1740, 1745 (2011) ("The FAA was enacted in 1925 in response to widespread judicial hostility to arbitration agreements."); see also Hiro N. Aragaki, Arbitration's Suspect Status, 159 U. PA. L. REV. 1233 (2011); Hiro N. Aragaki, Equal Opportunity for Arbitration, 58 UCLA L. REV. 1189 (2011) (collectively, theorizing that Court's FAA preemption jurisprudence is animated by an anti-discrimination principle and that the FAA prohibits laws that discriminate against arbitration). In any event, to the extent that Congress may have demonstrated an anti-arbitration bias in enacting $\$ 15(0)$, that recent expression of policy supersedes the FAA.

247. AT\&T Mobility, $131 \mathrm{~S}$. Ct. at 1748 .

248. Even under the slightly more stringent standards of the traditional implied repeal test, the SEC's statutory and regulatory authority over PDAAs would strongly support an implied repeal of the FAA. The facts would be difficult to distinguish from United States v. National Association of Securities Dealers, 422 U.S. 694 (1975), which also upheld rules promulgated by non-governmental entities and approved by the SEC in an area where Congress subsequently gave an explicit grant of regulatory discretion. See supra notes 213 16 and accompanying text.

249. SEC SPECIAL STUDY, supra note 100, at 153 (explaining the importance of protecting investors through uniform minimum standards of competence, experience, character and capital).

250. Id. at 237 (describing "fiduciary and quasi-fiduciary obligations" that brokerdealers owe to deal fairly with the public). 
whom they conduct business; believing that their brokers are treating them fairly is an essential component of investor trust and confidence. ${ }^{251}$ As a result, active regulation of the dispute resolution forum used to resolve virtually all customer-broker disputes affects "practices that lie squarely within an area of financial market activity that the securities law seeks to regulate." 252

In our view, therefore, Congress' delegation of power to the SEC and FINRA to regulate all aspects of the broker-dealer industry, found in Exchange Act $\S 15 \mathrm{~A}$, including specifically PDAAs in Exchange Act $\S 15(0)$, displaces the expression of national policy embodied in the FAA to enforce arbitration agreements in accordance with their terms. In short, brokerage firms should not be able to invoke the FAA to justify their removal of investors' class action remedy when conflicting FINRA rules mandate that customers have access to that remedy.

\section{Deference to SEC as an administrative agency}

To the extent there is any ambiguity as to whether FINRA's rules bar class action waivers in customer agreements, courts should give substantial deference to the SEC's interpretation of its own rule-making authority and FINRA's interpretation of its Commission-approved rules. ${ }^{253}$

Courts give substantial deference to an administrative agency's interpretation of an ambiguous statute $\mathrm{e}^{254}$ as well as an administrative rule that interprets the issuing agency's own ambiguous regulation. ${ }^{255}$ An agency interpreting an ambiguous statute may receive substantial deference if "Congress delegated authority to the agency generally to make rules carrying the force of law, and that the agency interpretation claiming deference was promulgated in the exercise of that authority." 256 Under the Chevron deference

251. POSER \& FANTO, supra note 98, at 1-5 (explaining that "[i]f ordinary investors come to believe that securities investing and trading benefit only insiders, the consequences could be disastrous for the capital markets").

252. Credit Suisse Sec. (USA) LLC v. Billing, 551 U.S. 264, 275-76 (2007).

253. See Roberta S. Karmel, Should Securities Industry Self-Regulatory Organizations Be Considered Government Agencies?, 14 STAN. J. L. Bus. \& FIn. 151, 152 (2008) (arguing that when FINRA exercises its investigative and disciplinary functions it should be viewed as a government agency); $c f$. AXA Distributors, LLC v. Bullard, 1:08-CV-188-WKW, 2008 WL 5411940, at *8 n.20 (M.D. Ala. Dec. 24, 2008) (FINRA's interpretations of its own regulations "factor into the analysis"). But see Morgan Keegan \& Co. v. Johnson, 2:11CV502, 2011 WL 7789796, at*7 (E.D. Va. Dec. 22, 2011) (FINRA's interpretation of its arbitration rules is not entitled to Chevron deference because FINRA is a nongovernmental agency and its regulations are not mandated by federal law).

254. See Chevron U.S.A. Inc. v. Natural Res. Def. Council, Inc., 467 U.S. 837, 842-45 (1984).

255. See Auer v. Robbins, 519 U.S. 452, 461-63 (1997).

256. United States v. Mead Corp., 533 U.S. 218, 226-27 (2001). Otherwise, the interpretation is "entitled to respect" only to the extent it has the "power to persuade." Skidmore v. Swift \& Co., 323 U.S. 134, 140 (1944). 
test, if the statute is silent or ambiguous with respect to the specific issue, the question for the court is whether the agency's answer is based on a permissible construction of the statute." 257

Ultimately, courts determine the degree of deference based on the circumstances of each case, considering factors such as the degree of the agency's care, its consistency, formality, relative expertness, and the persuasiveness of its position. ${ }^{258}$ If the agency's action carries the force of law, then it is entitled to deference. An agency's authority to engage in adjudication or "notice and comment" rulemaking, defined in the Administrative Procedure Act (5 U.S.C. $§ 553$ ), is a strong indication that Congress intended the agency to create rules that carry the force of law. ${ }^{259}$ Deference may be broadened when the regulation concerns "a complex and highly technical regulatory program" in which the identification and classification of relevant "criteria necessarily require significant expertise and entail the exercise of judgment grounded in policy concerns." 260

The Commission expressly stated that it enacted the predecessor to Rule 2268 for the specific purpose of ensuring that investors have access to courts for class action claims. ${ }^{261}$ In its approval order, the Commission noted that the new rule "will ensure that arbitration agreements clearly state the class action claims are specifically outside the scope of arbitration contracts entered into by members." 262 As discussed above, the SEC clearly had Congressional authority to act in this context. ${ }^{263}$ In determining a question of implied repeal in earlier cases, the Court stated that a "consistent and longstanding interpretation by the agency charged with administration of the Act [the SEC], while not controlling, is entitled to considerable weight." ${ }^{264}$ Moreover, FINRA rules are approved by

257. Chevron, 467 U.S. at 842-43. "The power of an administrative agency to administer a congressionally created ... program necessarily requires the formulation of policy and the making of rules to fill any gap left, implicitly or explicitly, by Congress." Morton v. Ruiz, 415 U.S. 199, 231 (1974).

258. United States v. Mead Corp., 533 U.S. 218, 228 (2001).

259. Id. at 234 .

260. Pauley v. BethEnergy Mines, Inc., 501 U.S. 680, 697 (1991); Thomas Jefferson Univ. v. Shalala, 512 U.S. 504, 512 (1994).

261. Order Approving Proposed Rule Change Relating to the Exclusion of Class Actions from Arbitration Proceedings, 57 Fed. Reg. 52,659, 52,661 (Nov. 4, 1992).

262. Id.

263. See supra notes $102-14$ and accompanying text. The Court already has accorded Chevron deference to the Commission's interpretation of section 10(b) and Rule 10b-5 in insider trading cases. United States v. O'Hagan, 521 U.S. 642, 673 (1997); SEC v. Zandford, 535 U.S. 813,820 (2002).

264. United States v. Nat'l Ass'n of Sec. Dealers, Inc., 422 U.S. 694, 719 (1975). To the extent that courts have declined to accord deference to other administrative agencies' findings of implied repeal of the FAA, those decisions are distinguishable in the context of the SEC's complex regulatory program. See Davis v. S. Energy Homes, Inc., 305 F.3d 1268, 1280 (11th Cir. 2002) (declining to give Chevron deference to FTC's interpretation of the MMWA on ground that FTC's construction of the statute was not reasonable, and noting that 
the SEC through "notice and comment" rule-making. ${ }^{265}$ Thus, courts should accord substantial deference to the Commission's and FINRA's view that FINRA Rule 2268 bars class action waivers in customer agreements.

\section{B. Exchange Act's Specific Rules Displace the FAA's General Mandate}

Another relevant canon of statutory construction provides that, in the context of interpreting and applying conflicting regulations, the more specific regulation trumps the general one. ${ }^{266}$ This rule applies when the difference between the specific and general rule is clear. It is also treated not as a firm rule of construction, but a factor often considered among other matters of fairness and conflict in order to determine exemptions. ${ }^{267}$ Pursuant to this canon of construction, any SEC or SRO rules affecting PDAAs would likely be controlling following the passage of Exchange Act $\S 15(0)^{268}$ and the amendment of Exchange Act $\S 29$ (a) to include SRO rules. ${ }^{269}$ The relevant language of the Exchange Act is more specific than any portion of the FAA that would apply to the Schwab agreement. This specific language in the Exchange Act accompanied by precise SRO rules would likely be enforced rather than the general mandates of the FAA.

Furthermore, the regulators devising these specific rules have far more expertise in this complex area than the generalist pronouncements of the Supreme Court interpreting the FAA. As we have described, the SEC and FINRA have, since McMahon, engaged in an ongoing examination and revision of the SRO arbitration process and its rules to meet the needs of investors, broker-dealers and the general public. Their rulemaking has been guided by two realities: (1) virtually all customers' disputes with their brokers are resolved in the SRO forum, and (2) investors' trust and confidence in their brokers is paramount to maintaining strong capital markets. Accordingly, the federal regulators, based on their understanding of the industry, have determined that some investors' claims can be better handled if aggregated. If

courts are split on the issue); LaVoice v. UBS Fin. Serv., Inc., 11 CIV. 2308 BSJ JLC, 2012 WL 124590 (S.D.N.Y. Jan. 13, 2012) (declining to give Chevron deference to D.R. Horton, 357 NLRB No. 184 (Jan. 3, 2012)). But see Jonathan D. Grosberg, The Magnuson-Moss Warranty Act, the Federal Arbitration Act, and the Future of Consumer Protection, 93 CORNELL L. REV. 659 (2008) (arguing that courts should give substantial deference to the Federal Trade Commission's view that the MMWA precludes binding arbitration in settlement procedures governed by the MMWA).

265. The Schwab district court found that FINRA rules carry the force of law for deference purposes. Charles Schwab \& Co. v. Fin. Indus. Regulatory Auth. Inc., 861 F. Supp. 2d 1063 (N.D. Cal. 2012).

266. See, e.g., Morales v. Trans World Airlines, Inc., 504 U.S. 374, $384-85$ (1992); Long Island Care at Home, Ltd. v. Coke, 551 U.S. 158, 170 (2007).

267. See Chickasaw Nation v. U.S., 534 U.S. 84, 94 (2001).

268. 15 U.S.C. $\$ 780(0)$ (Supp. V 2011).

269. See supra note 122 and accompanying text. 
there are a discrete number of similar claims, FINRA permits joinder in the arbitration forum; if, however, claims can be better handled in a class action, FINRA has determined that investors should have the opportunity to present these claims in court. The SEC has approved FINRA's judgment that fair treatment and investor protection require that investors should have access to courts for class actions.

The Supreme Court, in contrast, is a generalist body that articulated, in $A T \& T$ Mobility, a broad national policy in favor of individual arbitration that at least some commentators believe is not in tune with practical realities. ${ }^{270}$ Yet, in previous challenges to SRO arbitration policies, the court deferred to the federal regulators' expertise. In Mastrobuono v. Shearson Lehman Hutton, ${ }^{271}$ the Court upheld the power of arbitrators to award punitive damages, although the customer agreement had a New York choice of law clause and New York law at that time did not permit arbitrators to award punitive damages. Similarly, in Howsam v. Dean Witter Reynolds, Inc., ${ }^{272}$ the Court held that arbitration panels, and not the courts, had the power to decide whether a SRO time limitation for bringing claims had expired. In both instances, the Court supported the SRO's position in the face of plausible contract arguments to the contrary. ${ }^{273}$ It is true that deference to FINRA policies was, in those cases, consistent with the Court's pro-arbitration policy, while deference to FINRA policy in the Schwab case could be viewed as inconsistent with $A T \& T$ Mobility's support for the class action waiver. Nevertheless, we submit that there is nothing in $A T \& T$ Mobility that establishes that class action waivers are enforceable notwithstanding federal regulators' determination that they are contrary to the public interest in a particular context.

Indeed, we recognize that the balancing of policy interests may well be different in other contexts. The importance of investors' trust and confidence in their broker-dealer relationships may not be applicable in other commercial relationships like the wireless service contract in $A T \& T$ Mobility. Accordingly, it would be unfortunate if the Court's unwavering support for the FAA to date is construed to prohibit federal regulators, acting pursuant to Congressional authority, from taking into account important policy considerations in constructing the appropriate dispute resolution system to deal with matters within their field of expertise.

270. Lawrence A. Cunningham, Rhetoric Versus Reality in Arbitration Jurisprudence: How the Supreme Court Flaunts and Flunks Contracts, 75 LAW \& CONTEMP. PROBS. 129, 144 (2012) (asserting that " $[\mathrm{t}] \mathrm{he}$ Court commits contradictions that manifest a lack of understanding of contract law and even life"). Professor Cunningham argues that there is a rhetoric-reality gap between the Court's incantations about arbitration as contract and the reality that the Court is promoting a particular form of arbitration over other methods of dispute resolution.

271. 514 U.S. 52 (1995).

272. 537 U.S. 79 (2002).

273. Cunningham, supra note 270 , at $138,148-49$. 


\section{Arguments Not Limited to the Broker-Dealer Context}

Thus far, we have focused on the dispute between FINRA and Schwab over the firm's prohibition against aggregating claims and have demonstrated how the SEC and FINRA's authority under the Exchange Act to prohibit the firm's contract term displaces contrary policy under the FAA. As previously noted, there have also been recent efforts to amend governance documents of publicly traded issuers to require arbitration and prohibit aggregation of claims. $^{274}$ The SEC opposed these corporate governance maneuvers on the ground that they would violate the federal securities laws. The SEC clearly took the position that, the FAA notwithstanding, the securities laws it was empowered to enforce prohibited public entities from inserting provisions in governance documents that would weaken investors' rights and remedies.

In this section we set forth additional arguments under the Exchange Act and the FAA that are broadly applicable to void any purported class-action waiver under the federal securities laws.

\section{The Exchange Act's anti-waiver provision}

An additional argument for the displacement of the FAA by the Exchange Act in the Schwab dispute that is applicable outside the context of brokerdealer regulation is also based on Exchange Act $§ 29(\mathrm{a})$ : a securities classaction waiver violates the anti-waiver provisions of the federal securities laws because the waiver effectively amounts to the loss of the individual investors' private remedy. As the McMahon majority stated, Exchange Act $\S 29$ (a) "is concerned with whether the agreement 'weakens [customers'] ability to recover under the Exchange Act.",275 It is well-established that $§ 29(a)$, as amended by Dodd-Frank, does not permit provisions that weaken investors' ability to recover under the federal securities laws, including FINRA rules, no matter what form they take. ${ }^{276}$ Schwab's combination of a PDAA, a class action waiver and a prohibition on combining claimants with similar claims means that the only remedy available to every customer is an individual claim,

274. See supra notes 37-50 and accompanying text.

275. Shearson/Am. Express, Inc. v. McMahon, 482 U.S. 220, 230 (1987) (quoting Wilko v. Swan, 346 U.S. 427 (1953)).

276. See, e.g., McMahan \& Co. v. Wherehouse Entm't, Inc., 65 F.3d 1044 (2d Cir. 1995) (analyzing a no-action clause in indenture); AES Corp. v. Dow Chemical Co., 325 F.3d 174 (3d Cir. 2003) (considering a non-reliance clause in stock purchase agreement); Vacold LLC v. Cerami, 545 F.3d 114, 122 (2d Cir. 2008) (addressing a release in stock purchase agreement); Special Transp. Servs., Inc. v. Balto, 325 F. Supp. 1185 (D. Minn. 1971) (considering a clause providing for alternative remedy); Citibank v. Itochu Int'l, Inc., 01 CIV. 6007 (GBD), 2003 WL 1797847 (S.D.N.Y. Apr. 4, 2003) (analyzing a clause specifying indemnification as sole remedy); Anglo-German Progressive Fund, Ltd. v. Concorde Group, Inc., 09 CIV 8708 PKC, 2010 WL 3911490 (S.D.N.Y. Sept. 14, 2010) (addressing a merger clause). 
however small the amount. Schwab's judgment that this is an adequate remedy $^{277}$ is not shared by the SEC, FINRA or academic commentary. ${ }^{278}$ Similarly, the proposals to include class action waivers in corporate governance documents also serve to eliminate, as a practical matter, remedies for investors with small federal securities claims. The high costs of pursuing federal securities claims means that, unless a class-wide remedy is available, there is, as a practical matter, no remedy for investors with small holdings. A class action waiver in this context is the equivalent of a surrender of investor protections prohibited by the anti-waiver provisions.

Ironically, Congress confirmed the importance of the federal securities class action in the PSLRA, legislation that came about largely through the lobbying efforts of the business community. The PSLRA sought to weed out frivolous suits through a variety of procedural and other measures, in lieu of eliminating federal securities class actions altogether, as business interests urged. ${ }^{279}$ In choosing to cure, but not to eliminate the securities class action, Congress determined that a collective-action remedy is necessary for investor protection, especially retail investors. ${ }^{280}$ In the PSLRA, Congress thus confirmed the importance of the federal securities class action to the integrity of the U.S. capital markets. ${ }^{281}$

\section{The class action waiver is unenforceable because investors cannot vindicate their statutory rights}

In addition to arguments grounded in the Exchange Act's specific language, arguments based on the Court's FAA jurisprudence also support

277. Charles Schwab \& Co., Inc.'s Notice of Motion and Motion for Preliminary Injunction; Memorandum of Points and Authorities in Support of Charles Schwab \& Co., Inc.'s Motion for Preliminary Injunction at 3-4, Charles Schwab \& Co. v. Fin. Indus. Regulatory Auth., Inc., (No. C-12-00518 EDL) 2012 WL 1408607 (stating that Schwab inserted the class action waiver after $A T \& T$ Mobility, "to protect its shareholders and customers from the high costs and inefficiencies associated with customer class actions" and "mindful of the fact that FINRA Dispute Resolution provides a successful arbitration forum for customers, including simplified arbitration for small claims").

278. See supra notes 174-75 and accompanying text; see also Gross, supra note 17 (arguing that small claims arbitration, which is primarily a document-based hearing, lacks procedural justice).

279. For a brief description of the key provisions, see DONNA M. NAGY, RichaRd W. Painter \& Margaret V. SAChS, SeCurities Litigation AND ENFORCEMENT CASES AND MATERIALS 10 (3d ed. 2012).

280. See H.R. REP. No. 104-369, at 31 (1995), reprinted in 1995 U.S.C.C.A.N. 730 (Conf. Rep.) ("The private securities litigation system is too important to the integrity of American capital markets to allow this system to be undermined by those who seek to line their own pockets by bringing abusive and meritless lawsuits.").

281. Id. In 1998 Congress reaffirmed the national importance of the reformed federal securities fraud class action and enacted the Securities Litigation Uniform Standards Act of 1998, Pub. L. No. 105-353, 112 Stat. 3227 (1998), which preempts most class actions filed under state common law and state securities statutes. 
voiding Schwab's class action waiver. Challengers to Schwab's class action waiver can also argue that it is unenforceable under the "vindicating statutory rights" doctrine. Under this doctrine, derived from the Supreme Court's pronouncement in Mitsubishi ${ }^{282}$ that "so long as the prospective litigant effectively may vindicate its statutory cause of action in the arbitral forum, the [federal] statute [providing that cause of action] will continue to serve both its remedial and deterrent function," a disputant can argue that an arbitration agreement is unenforceable because an unfair aspect of the arbitration process would preclude that party from vindicating its statutory rights. ${ }^{283}$ Proposals to include class action waivers in corporate governance documents are similarly unenforceable under Mitsubishi.

Lower courts have applied this doctrine post-AT\&T Mobility to void class action waivers in non-securities contexts. For example, in In re American Express Merchants' Litigation, ${ }^{284}$ a purported class action arising under federal antitrust laws, the Second Circuit Court of Appeals reconsidered, in light of $A T \& T$ Mobility, its prior decisions that a class action waiver clause in a credit card agreement was unenforceable under the FAA ${ }^{285}$ because "enforcement of the clause would effectively preclude any action seeking to vindicate the [plaintiffs'] statutory rights." ${ }^{286}$ The Court of Appeals found that $A T \& T$ Mobility did not alter its prior analysis, which rested on a different ground than AT\&T Mobility. ${ }^{287}$ Rather, the Court of Appeals recognized, "[h]ere. . our holding rests squarely on a "vindication of statutory rights analysis, which is part of the federal substantive law of arbitrability." 288 Because plaintiffs demonstrated through expert testimony that pursuing their statutory claims individually, as opposed to through class arbitration, would not be economically feasible, thereby "effectively depriving plaintiffs of the statutory

282. Mitsubishi Motors Corp. v. Soler Chrysler-Plymouth, Inc., 473 U.S. 614, 637 (1985)

283. See Green Tree Fin. Corp.-Ala. v. Randolph, 531 U.S. 79, 92 (2000) (recognizing in dicta that, if a party showed that pursuing its statutory claims through arbitration would be prohibitively expensive, and thus it could not vindicate its statutory rights, a court could validly refuse to enforce a PDAA).

284. See In re Am. Express Merchs.' Litig., 667 F.3d 204 (2d Cir. 2012) (Amex III), cert. granted sub nom. American Exp. Co. v. Italian Colors Restaurant, 133 S.Ct. 594 (2012).

285. See In re Am. Express Merchs.' Litig., 634 F.3d 187 (2d Cir. 2011) (Amex II); In re Am. Express Merchs.' Litig., 554 F.3d 300 (2d Cir. 2009) (Amex I). The Court of Appeals reconsidered Amex I in light of the Supreme Court's subsequent ruling in Stolt-Nielsen S.A. v. AnimalFeeds Int'l Corp., 130 S. Ct. 1758 (2010).

286. Amex I, 554 F.3d at 304.

287. See Amex III, 667 F.3d at 214 ("What Stolt-Nielsen and Concepcion do not do is require that all class-action waivers be deemed per se enforceable. That leaves open the question presented on this appeal: whether a mandatory class action waiver clause is enforceable even if the plaintiffs are able to demonstrate that the practical effect of enforcement would be to preclude their ability to bring federal antitrust claims.").

288. Id. at 213 (quoting Amex I, 554 F.3d at 320). 
protections of the antitrust laws, ${ }^{289}$ the Second Circuit directed the district court to deny defendant's motion to compel arbitration. ${ }^{290}$

Schwab customers could argue that the class action and joinder waiver in their PDAA precludes their ability to effectively bring claims arising under the Exchange Act against Schwab. Scholars and practitioners alike concur that, absent the class action mechanism, disputants aggrieved through misconduct by an entity with superior bargaining power-although in small amounts individually but large amounts collectively - have no legal remedy that is economically feasible to pursue. ${ }^{291}$ In the context of securities fraud class

289. Id. at 217.

290. Id. at 219-20; see also Chen-Oster v. Goldman, Sachs \& Co., No. 10 Civ. 6950 (LBS) (JCF), 2011 WL 2671813, at *3 (S.D.N.Y July 7, 2011) (refusing to reconsider its holding in a Title VII action that an arbitration clause was unenforceable because plaintiffs would not be able to vindicate their statutory rights absent the availability of class proceedings and distinguishing AT\&T Mobility); Sutherland v. Ernst \& Young LLP, 10 Civ. 3332, No. 10 Civ. 3332 (KMW) (MHD), 2012 WL 130420, at *12-14 (S.D.N.Y. Jan. 17, 2012) (reaffirming earlier invalidation of an employment agreement waiver that would have precluded putative FLSA collective litigation because it would "operate as a waiver of Sutherland's right to pursue her statutory remedies pursuant to FLSA"); In re Elec. Books Antitrust Litig., No. 11 MD 2293 (DLC), 2012 WL 2478462, at *4 (S.D.N.Y. June 27, 2012) (denying motion to compel arbitration of antitrust claims pursuant to arbitration clause with class action waiver under vindicating rights doctrine). But see Homa v. Am. Express Co., No. 11-3600, 2012 WL 3594231 (3d Cir. Aug. 22, 2012) (finding that AT\&T Mobility requires enforcing the class waiver provision even though plaintiff established that individual arbitration would not vindicate his statutory rights).

291. Judge Craig Smith \& Judge Eric V. Moyé, Outsourcing American Civil Justice: Mandatory Arbitration Clauses in Consumer and Employment Contracts, 44 TEX. TECH L. REV. 281, 295 (2012) (AT\&T Mobility "sounds a death knell for consumer class actions ... . Alone, these small-dollar claims appear insignificant and are far less likely to see their day in court. In its decision, the Court acknowledged this concern and did not dispute its seriousness; however, it did not find these concerns sufficient to protect in the face of the stated controlling policy"); Jean Sternlight, Tsunami: AT\&T Mobility LLC v. Concepcion Impedes Access to Justice, 90 OR. L. REV. 703, 704 (2012) ("It is highly ironic but no less distressing that a case with a name meaning 'conception' should come to signify death for the legal claims of many potential plaintiffs."); S.I. Strong, Does Class Arbitration 'Change the Nature' of Arbitration? Stolt-Nielsen, AT\&T and a Return to First Principles, 17 HARV. Negot. L. Rev. 201 (2012); Ann Marie Tracey \& Shelley McGill, Seeking a Rational Lawyer for Consumer Claims After the Supreme Court Disconnects Consumers in AT\&T Mobility LLC v. Concepcion, 45 Loy. L.A. L. REv. 435, 435-36 (2012) (“[The] Court essentially eliminated one of the few methods, if not the only method, that consumers have to adjudicate legitimate claims that likely could not or would not be brought on an individual basis. This decision insulates companies from any meaningful liability that may result from poor practices or even fraudulent schemes."); Sarah Cole, Continuing the Discussion of the AT\&T v. Concepcion Decision: Implications for the Future, ADR PROF BLOG (Apr. 27, 2011), http://www.indisputably.org/?p=2312 ("It would appear that the era of class arbitration is over before it really ever began - unless Congress can be persuaded to amend the FAA to permit class arbitration, at least in cases involving low value claims, where consumers are unlikely to have practical recourse to a remedy through traditional bilateral arbitration."); Marcia Coyle, Divided Justices Back Mandatory Arbitration for Consumer Complaints, N.Y. L.J., Apr. 28, 2011 (quoting a lawyer for the Concepcions, stating " " $[\mathrm{t}] \mathrm{he}$ decision will make it harder for people with civil rights, labor, consumer and other kinds of 
arbitration, the Second Circuit's analysis in Amex III is even more compelling. Based on the need to use experts to establish elements such as causation, reliance and damages, ${ }^{292}$ the costs of proving a federal securities fraud claim in arbitration would be so large as to make pursuing an individual claim infeasible except possibly for large investors that have suffered significant losses. Thus, individual investors can establish that, under Mitsubishi, an arbitration clause with a class action waiver is not enforceable because they would not be able to vindicate their statutory rights in individualized, small claims arbitration.

\section{CONCLUSION}

Persuasive statutory, legal and policy reasons support the contention that Schwab cannot seek refuge in the FAA to force its customers to waive their rights to pursue a class action or consolidated arbitration against the firm. Schwab's efforts to effectively immunize itself from liability against individual retail customers for misconduct impacting more than one customer at a time contradicts existing statutory protections for investors found throughout the Exchange Act. Congress' more recent and quite specific pronouncement combined with its delegation of rule-making authority over broker-dealers to the SEC - which is uniquely situated in a complex regulatory environment with the requisite expertise to exercise sound judgment and devise policies and rules to further its statutory mandate of investor protection-displaces the Supreme Court's general pronouncement that arbitration agreements should be enforced according to their terms. This general pronouncement is not absolute: exceptions abound for, inter alia, contrary Congressional commands, common law contract defenses applicable to all contracts, and agreements that do not permit disputants to vindicate their statutory rights. While AT\&T Mobility empowers courts to preempt state laws displaying anti-arbitration bias, and CompuCredit permits the arbitrability of statutory claims in the absence of conflicting federal regulations, no authority exists for the astounding proposition that Schwab has advanced: that the FAA limits the ability of federal regulators acting pursuant to authority under Exchange Act to impose conditions and limitations on the use of arbitration provisions in customer agreements in order to protect investors and ensure fairness.

At its core, reconciling conflicting federal statutes boils down to distilling Congressional intent. Congress has not yet passed a law banning predispute arbitration agreements in most consumer PDAAs, although it has given the

claims that stem from corporate wrongdoing to join together to obtain their rightful compensation"” (internal quotation marks omitted)).

292. See supra note 32 and accompanying text; Michael J. Kaufman, Regressing: The Troubling Dispositive Role of Event Studies in Securities Fraud Litigation, 15 STAN. J.L. Bus. \& FIN. 183 (2009) (explaining the barriers to meritorious securities fraud litigation presented by the need for event studies prepared by qualified events). 
matter serious consideration. ${ }^{293}$ Unless and until it does, AT\&T Mobility fortifies class action waivers in consumer PDAAs against challenges under state laws. The assertion that $A T \& T$ Mobility extends to bar all challenges to class action waivers under federal regulatory statutes, however, is overbroad and does not withstand careful analysis under federal securities laws, perhaps other federal statutes, and canons of statutory construction.

293. See supra note 147 and accompanying text. 